\title{
PEMIMPIN YANG MEMILIKI INTEGRITAS \\ MENURUT 2 TIMOTIUS PASAL 2
}

\author{
Maria Rukku \\ sttjaffraymakassar@yahoo.co.id \\ Daniel Ronda \\ danielronda@ymail.com
}

\begin{abstract}
ABSTRAK
Penulisan ini bertujuan untuk merumuskan suatu konsep mengenai pemimpin yang memiliki integritas yang diperlukan pada masa kini. Dalam penulisan penulisan ini sebagai suatu karya ilmiah dibutuhkan suatu metode penelitian yang tepat guna mendapatkan data yang konkret.

Kaitannya dengan itulah maka di sini penulis akan menguraikan sumber data dan teknik pengumpulan data yang dipakai dalam penyusunan penulisan ini sebagai berikut: Pertama, yaitu pengambilan data melalui eksposisi Alkitab yang dijabarkan secara deskriptif. Kedua, yaitu pengambilan data melalui buku-buku perpustakaan yang ada kaitannya dengan pokok penulisan ini sebagai penunjang eksposisi Alkitab. Alkitab menjadi sumber utama dalam penulisan penulisan ini. Ketiga, yaitu pengambilan data melalui penelitian lapangan yaitu melalui wawancara dengan tujuan menunjang eksposisi Alkitab.

Setelah pembahasan yang relatif panjang tentang pemimpin yang memiliki integritas, maka dapat disimpulkan bahwa integritas sungguh sangat penting bagi seorang pemimpin. Integritas perlu bagi para pemimpin supaya pilar-pilarnya menjadi superstruktur. Integritas adalah kekuatan konstruksi kepemimpinan.

Bahwa dalam kehidupan seorang pemimpin tidak hanya harus memiliki suatu kehidupan kerohanian yang tinggi tetapi juga harus ditunjang oleh integritas diri dalam kepemimpinannya. Bobot kepemimpinan tidak ditentukan oleh tingginya pendidikan semata atau banyaknya jam terbang dalam pelayanan, melainkan oleh integritas diri.

Pecahnya Kerajaan Israel, hancurnya Kerajaan Yehuda adalah karena rapuhnya integritas para pemimpinnya. Keruntuhan masyarakat juga diawali dengan pemimpin yang kehilangan integritasnya, yang berakibat runtuhnya sendi-sendi norma masyarakat, seperti ayah tidak menjadi teladan, anak-anak mencari figur dari film, televisi dan media lainnya.

Bahwa pemimpin yang berintegritas adalah pemimpin yang selalu mematutkan hidupnya dengan Firman Tuhan, bergantung penuh pada pimpinan Roh Kudus, mengusahakan karakter yang baik, dan selalu menunjukkan sikap kerendahan hati.
\end{abstract}

Kata Kunci: Pemimpin, Integritas 


\section{PENDAHULUAN}

\section{Latar Belakang Masalah}

Dalam Kejadian 20:1-6 dikisahkan tentang Abraham dan Sara, istrinya, pada waktu mereka tinggal di Gerar, di antara Kadesh dan Syur di Tanah Negeb, di mana Abimelekh, raja negeri itu, menyuruh mengambil Sara baginya, karena Abraham dan Sara mengaku sebagai saudara. Di dalam Firman Tuhan dikatakan, demikian:

Lalu Abraham berangkat dari situ ke Tanah Negeb dan ia menetap antara Kadesh dan Syur. Ia tinggal di Gerar sebagai orang asing. Oleh karena Abraham telah mengatakan tentang Sara, isterinya: "Dia saudaraku," maka Abimelekh, raja Gerar, menyuruh mengambil Sara. Tetapi pada waktu malam Allah datang kepada Abimelekh dalam suatu mimpi serta berfirman kepadanya: "Engkau harus mati oleh karena perempuan yang telah kauambil itu; sebab ia sudah bersuami." Adapun Abimelekh belum menghampiri Sara. Berkatalah ia: "Tuhan! Apakah Engkau membunuh bangsa yang tak bersalah? Bukankah orang itu sendiri mengatakan kepadaku: Dia saudaraku? Dan perempuan itu sendiri telah mengatakan: Ia saudaraku. Jadi hal ini kulakukan dengan hati yang tulus dan dengan tangan yang suci."Lalu berfirmanlah Allah kepadanya dalam mimpi: "Aku tahu juga, bahwa engkau telah melakukan hal itu dengan hati yang tulus, maka Aku pun telah mencegah engkau untuk berbuat dosa terhadap Aku; sebab itu Aku tidak membiarkan engkau menjamah dia.

Dalam kisah ini, di satu sisi, kita belajar tentang integritas di mana tokoh iman yang berotoritas dan yang berpengaruh serta berstatus, melanggar kejujuran. Sementara di sisi lain, seorang raja kafir justru menanggapinya dengan integritas.

Menurut John C. Maxwell yang dikutip oleh Henoch F. Saerang, bahwa seseorang yang memiliki integritas, kata-katanya dan perbuatannya selalu selaras. Ia ada sebagaimana ia ada, tidak perduli di mana pun dan dengan siapa pun ia. Seseorang yang memiliki integritas tidak terbagi atau berpura-pura. Ia adalah "seutuhnya" dan kehidupannya terhimpun bersama. Seseorang yang memiliki integritas tidak akan menyembunyikan sesuatu dan tidak takut pada apa pun. Hidupnya bagaikan buku yang terbuka, semuanya dapat didemonstrasikan setiap hari. ${ }^{1}$

Dalam berbagai bagian Alkitab, ditemukan bahwa integritas itu penting karena Tuhan menginginkannya (Kejadian 17:1; 1 Petrus 5:4-6), hal itu merefleksikan diri yang sebenarnya (Kejadian 20:5-6), manusia membutuhkannya (Amsal 10:9, 20:7; 1 Raja-raja 9:4-5; Filipi 2:14-16; 1 Timotius 4:12).

\footnotetext{
${ }^{1}$ Henoch F. Saerang, "Integrity”, Local Leadership Training Programme, Makassar: 10-13 Oktober 2007, 3
} 
Kecerdasan otak memang penting namun tidak berguna bagi sesama manusia jika tidak diimbangi dengan integritas. Banyak orang beranggapan bahwa integritas adalah modal utama seorang pemimpin atau seorang hamba Tuhan, namun sekaligus modal yang paling langka dimiliki oleh pemimpin. Inilah ironi terbesar dalam area kepemimpinan. Denis Waitley, mengatakan:

Integritas, sebuah standar moralitas dan etika pribadi, tidak ada hubungannya dengan situasi yang kebetulan ada di sekitar Anda dan tidak mendorong kecepatan. Persediaannya yang sedikit kini semakin sedikit - tetapi tanpa integritas, kepemimpinan hanyalah pulasan. ${ }^{2}$

James Kousez dan Barry Posner, dua orang peneliti kawakan, dalam buku mereka yang berjudul Credibility: How leaders gain and lose it, why people demand it melaporkan hasil riset mereka selama hampir 20 tahun dari hasil survey terhadap ribuan profesional dari empat benua dan ratusan studi kasus bahwa faktor nomor satu yang paling kritikal bagi seorang pemimpin adalah integritas. ${ }^{3}$

Warren Bennis dalam bukunya Leaders: Strategies for Taking Charge menulis bahwa integritas adalah fondasi untuk membangun rasa percaya (trust). Trust ini berkaitan erat dengan predictability. Seorang pemimpin yang memiliki integritas membangun trust dengan menunjukkan kepada orang lain bahwa apabila diperhadapkan dengan tantangan moral, segala keputusan dan aksinya dapat diprediksi. ${ }^{4}$

Sayang sekali, bahwa integritas juga merupakan kualitas yang paling langka, bahkan oleh banyak orang, disebutkan sebagai kualitas yang hampir punah. Senada dengan ini, John C. Maxwell, mengatakan: "Sayangnya, integritas merupakan komoditi yang mulai lenyap pada zaman sekarang. Standar pribadi sedang runtuh di dunia yang mati-matian mengejar kesenangan pribadi dan jalan pintas menuju sukses."

Kasus Samsul Bahri, anggota Komisi Pemilihan Umum (KPU) terpilih yang belum dilantik Presiden Susilo Bambang Yudhoyono ${ }^{6}$ karena dugaan korupsi Kawasan Industri Masyarakat Perkebunan (Kimbun) ${ }^{7}$ sangat memprihatinkan. Kini, Profesor ilmu pertanian, yang menjadi ketua

\footnotetext{
${ }^{2}$ Denis Waitley, Kerajaan Pikiran: Pelajaran Untuk Memimpin dan Berhasil di Dunia Yang Berdasarkan Pengetahuan. (Jakarta: Binarupa Aksara, 1996), 74

3 "Integritas, Bukan Karisma," dominggus.com, diakses tanggal 7 Nopember 2007, tersedia di http://www.dominggus.com/arsip/2005/01/06/integritas-bukan-karisma

${ }^{4}$ Ibid,-

${ }^{5}$ John C. Maxwell, Mengembangkan Kepemimpinan di Dalam Diri Anda. (Jakarta: Binarupa Aksara, 1995), 37

6 "Samsul Bahri Belum Menjadi Anggota KPU," menkokesra.go.id, diakses tanggal 9 Nopember 2007 tersedia http://www.menkokesra.go.id/index2.php?option=com_content\&ddo_pdf=1\& \&id=5942

7 "Samsul Bahri Dijenguk Koleganya Dari Unibraw," hariansib.com, diakses tanggal 9 Nopember 2007, tersedia di http://www.hariansib.com/2007/11/03/samsul-bahridijenguk-koleganya-dari-unibraw/
} 
Lembaga Pengabdian Masyarakat (LPM) Universitas Brawijaya Malang itu, sedang mendekam di Lembaga Pemasyarakatan (LP) Lowokwaru Malang, sejak hari Jumat, tanggal 2 Nopember $2007^{8}$

Anggota KPU terpilih untuk periode 2007-2012 itu tersangkut dalam kasus dugaan korupsi proyek pembangunan Kawasan Industri Gula Milik Masyarakat, Kabupaten Malang senilai Rp. 1,1 miliar. Dalam kasus tersebut, guru besar Fakultas Pertanian Unibraw itu menjadi salah satu tersangka." Versi lain mengatakan bahwa Samsul Bahri menjadi konsultan pada proyek, yang oleh Kejaksaan Agung ditengarai merugikan negara sebesar Rp 489 juta. 10

Kasus lain yang cukup memprihatinkan dan kini menyedot perhatian banyak kalangan adalah pemeriksaan terhadap majelis hakim Pengadilan Negeri Medan yang mengadili kasus korupsi dan pembalakan liar dengan terdakwa Adelin Lis. ${ }^{1 l}$ Selanjutnya, Kompas, menulis:

Menurut Aspar Siagian dari Humas Pengadilan Tinggi Sumatra Utara, Jumat, pemeriksaan terhadap hakim yang memeriksa kasus Adelin Lis adalah tindak lanjut dari perintah Mahkamah Agung. Hakim yang diperiksa adalah Jarasmen Purba, Ahmad Semma, dan Dolman Sinaga. "Dua hakim lain, yakni Robinson Tarigan dan Arwan Byrin selaku ketua majelis, diperiksa hari Senin bersama panitera Daud Purba, dan Leonardus Sinaga," kata Aspar lagi. ${ }^{12}$

Kasus ini menjadi menarik untuk diperhatikan karena bersinggungan langsung dengan lembaga yang diharapkan bahwa semua personelnya adalah orang-orang yang memiliki integritas pribadi yang baik.

Kenyataan seperti ini membersitkan sebuah kefrustrasian yang membelit dunia dan gereja. Dunia dan warga gereja menjadi kebingungan mencari figur yang bisa menjadi teladan mereka. Karena para pemimpinpun, yang seharusnya menjadi contoh dan teladan, telah berulang kali gagal dan gagal. ${ }^{13}$

Khusus untuk para pelayan Tuhan, Fred Smith, seorang penulis, mengatakan:

Jika kita akan mengerjakan pekerjaan Tuhan dengan cara Tuhan, kita harus mulai dengan karakter. Para pemimpin mempunyai tanggung jawab untuk membentuk dan mengembangkan karakter dan integritas. Pemimpin kristen perlu menguji diri sendiri sehingga mereka bersama

\footnotetext{
8 “Anggota KPU Terpilih Dipenjara," Fajar, 3 Nopember 2007, 1

${ }^{9}$ Ibid,-

10 "Pelantikan Anggota KPU Sesuai UU," poskota.co.id, diakses tanggal 9 Nopember 2007, tersedia di http://www.poskota.co.id/news_baca.asp?id=39992\& \&ik=6

11 "Majelis Hakim Mulai Diperiksa," Kompas, 10 Nopember 2007, 15

${ }^{12}$ Ibid,-

13 "Integritas, Bukan Karisma," dominggus.com, diakses tanggal 7 Nopember 2007, tersedia di http://www.dominggus.com/arsip/2005/01/06/integritas-bukan-karisma
} 
rasul Paulus dapat berkata, "Ikutlah aku, sebagaimana aku mengikut Kristus." ${ }^{14}$

Berdasarkan hal tersebut di atas maka penulis mengangkatnya dalam suatu karya tulis dan mencoba memberi solusi bagi pemimpin yang akan memiliki integritas. Karena dunia dan gereja sangat membutuhkan orangorang yang demikian sehingga penulis mengadakan suatu analisis "Pemimpin Yang Memiliki Integritas Menurut 2 Timotius Pasal 2."

\section{Pokok Masalah}

Dengan memperhatikan latar belakang di atas penulis dapat merumuskan pokok masalah, pertama, apa yang menyebabkan seorang pemimpin tidak memiliki integritas, dan yang kedua, bagaimana seorang pemimpin membangun gaya hidup yang berintegritas.

\section{Pembatasan Masalah}

Pemimpin yang memiliki integritas merupakan pokok bahasan yang sangat luas dan tidaklah mungkin untuk membahasnya sampai tuntas pada tempat yang sangat terbatas ini. Karena itu penulis membatasi ruang lingkup pembahasannya khusus pada "Pemimpin Yang Memiliki Integritas Menurut Surat 2 Timotius Pasal 2".

\section{Hipotesis}

Diduga bahwa apabila konsep mengenai pemimpin yang memiliki integritas yang dikemukakan penulis dalam Penulisan ini dipahami dan diaktualisasikan di dalam hidup dan kehidupan para pemimpin, maka para pemimpin tersebut akan menjadi pemimpin-pemimpin yang memiliki integritas yang dibutuhkan oleh dunia dan gereja yang menghasilkan pengaruh dan kuasa dalam pelayanannya.

\section{Tujuan Penulisan}

Penulisan penulisan ini selain bertujuan untuk memenuhi persyaratan akademik dalam rangka penyelesaian studi pada Sekolah Tinggi Theologia Jaffray di Makassar, juga bertujuan untuk merumuskan suatu konsep mengenai pemimpin yang memiliki integritas yang diperlukan pada masa kini.

\section{Metode Penelitian}

Dalam penulisan penulisan ini sebagai suatu karya ilmiah dibutuhkan suatu metode penelitian yang tepat guna mendapatkan data yang konkret. Dalam kaitan dengan itulah maka di sini penulis akan menguraikan sumber data dan teknik pengumpulan data yang dipakai dalam penyusunan penulisan ini sebagai berikut: Pertama, yaitu pengambilan data melalui

\footnotetext{
${ }^{14}$ Fred Smith, Memimpin Dengan Integritas. (Jakarta: YPI Immanuel, 2002), hal. 12
} 
eksposisi Alkitab yang dijabarkan secara deskriptif. Kedua, yaitu pengambilan data melalui buku-buku perpustakaan yang ada kaitannya dengan pokok penulisan ini sebagai penunjang eksposisi Alkitab. Alkitab menjadi sumber utama dalam penulisan penulisan ini. Ketiga, yaitu pengambilan data melalui penelitian lapangan yaitu melalui wawancara dengan tujuan menunjang eksposisi Alkitab.

\section{PEMIMPIN YANG MEMILIKI INTEGRITAS MENURUT SURAT 2 TIMOTIUS PASAL 2}

Kepada Timotius, pemimpin yang masih muda itu, Rasul Paulus menulis: "Apa yang telah engkau dengar dari padaku di depan banyak saksi, percayakanlah itu kepada orang-orang yang dapat dipercayai, yang juga cakap mengajar orang lain" (2 Timotius 2:2).

Dalam kaitannya dengan seorang pemimpin, penekanan dari apa yang disampaikan oleh Rasul Paulus kepada Timotius adalah yang "dapat dipercayai" dan "cakap mengajar" orang lain. Dengan kata lain, bahwa pemimpin yang diinginkan oleh Tuhan, adalah pemimpin yang dapat dipercayai dan pemimpin yang cakap mengajar orang lain.

M. Tafrikhan Marzuki, direktur INDES Semarang, mengatakan: "Seorang pemimpin harus punya integritas pribadi yang baik ... Integritas yang baik adalah individu yang memiliki integritas dalam dua wilayah sekaligus, yakni integritas moral dan integritas intelektual."16 Hal yang sama juga dikatakan oleh A.B. Susanto:

Seorang pemimpin harus mempunyai integritas yang tinggi dan berusaha untuk membawa kelompoknya ke arah yang benar atau ke arah yang lebih menguntungkan, yang lebih merupakan tujuan bersama daripada tujuan pribadi sang pemimpin. ${ }^{17}$

Johny The, mengatakan: "Ketika menasihati Timotius dalam menyeleksi calon-calon pemimpin gereja, Paulus mengatakan, hendaklah ia juga mempunyai nama baik di luar jemaat, agar jangan ia digugat orang dan jatuh ke dalam jerat Iblis (1 Timotius 3:7)." Gene Getz sebagaimana dikutip oleh Larry Crabb, bahwa: "Ketika Paulus memerintahkan Timotius dan Titus untuk mencari orang-orang untuk posisi kepemimpinan, ia memerintahkan mereka untuk mencari beberapa

\footnotetext{
${ }^{15}$ Huruf tebal ditambahkan oleh penulis.

16 M. Trafikhan Marzuki, "Mencari Figur Gubernur Ideal," suaramerdeka.com, diakses tanggal 9 Nopember 2007, tersedia di http://www.suaramerdeka.com /harian/02/09/24/kha2.htm 10

${ }^{17}$ A.B. Susanto, Meneladani Jejak Yesus Sebagai Pemimpin. (Jakarta: PT Grasindo, 1997),

${ }^{18}$ Johny The, Menjadi Pemimpin Unggul Dengan Strategi Marketing Paulus. (Yogyakarta: Yayasan Andi, 2006), 21.
} 
karakteristik tertentu yang dapat diamati, yang bila diambil semua mencerminkan kedewasaan."19

Dalam Alkitab, firman Tuhan, mengatakan: banyak yang terpanggil, tetapi sedikit yang terpilih (Matius 22:14). Banyak yang masuk sekolah tinggi teologi, mendapatkan ijazah dan gelar, tetapi sedikit yang dapat dipercayai. Sedikit yang memiliki integritas.

Dalam 2 Timotius 2 terdapat prinsip-prinsip tentang pemimpin yang berintegritas, yang penulis akan jelaskan sebagai berikut:

\section{Pemimpin yang Dapat Dipercayai}

Menurut 2 Timotius 2:2 pemimpin yang memiliki integritas adalah pemimpin yang “dapat dipercayai." Dengan kata lain, pemimpin yang memiliki integritas adalah pemimpin yang memperoleh kepercayaan. Kalau tidak demikian maka tidak akan ada orang yang mau menjadi pengikut. John C. Maxwell dan Yakob Tomatala, dalam tulisan masing-masing, mengatakan bahwa pemimpin adalah seseorang yang punya pengikut. ${ }^{20}$

Paulus menasihati Timotius supaya, sebagai seorang pemimpin, ia menyiapkan pemimpin-pemimpin lain yang mendapat kepercayaan. Untuk mempercayai seorang pemimpin, tidak perlu kita setuju dengannya. Kepercayaan adalah keyakinan bahwa pemimpin sungguh-sungguh dengan apa yang dikatakannya. Itu adalah kepercayaan kepada sesuatu yang sangat kuno yang disebut integritas. ${ }^{21}$

\section{Pemimpin yang Hidup Dalam Kekudusan}

Dalam 2 Timotius 2:21 dikatakan, bahwa "Jika seorang menyucikan dirinya dari hal-hal yang jahat, ia akan menjadi perabot rumah untuk maksud yang mulia, ia dikuduskan, dipandang layak untuk dipakai tuannya dan disediakan untuk setiap pekerjaan yang mulia." Menurut Paulus bahwa seseorang yang dapat dipercayai adalah seseorang yang telah dikuduskan. Dan dalam konteks kepemimpinan dapat dikatakan bahwa pemimpin yang dapat dipercayai adalah pemimpin yang telah dikuduskan atau pemimpin yang hidup dalam kekudusan.

Dalam Kitab Nabi Yesaya pasal 6 ayat 3, dikatakan, "Kudus, kudus, kuduslah TUHAN." Penekanan tiga kali dari ayat ini adalah salah satu dari banyak bagian yang menekankan kekudusan Allah. Kekudusan berasal dari

\footnotetext{
${ }^{19}$ Larry Crabb, Konseling Yang Efektif e Alkitabiah. (Yogyakarta: Yayasan Andi dan Bandung: Kalam Hidup, 1995), 24-25.

20 John C. Maxwell, Mengembangkan Kepemimpinan di Sekeliling Anda. (Jakarta: Professional Books, 1997), 4; Yakob Tomatala, "Kepemimpinan Kristen: Apakah Itu?," lead.sabda.org; diakses tanggal 2 Nopember 2007; tersedia di http://www.lead.sabda.org/?title=menemukan_pemimpin_kompeten

${ }^{21}$ Yakob Tomatala, "Kepemimpinan Kristen: Apakah Itu?," lead.sabda.org; diakses tanggal 2 Nopember 2007; tersedia di http://www.lead.sabda.org/?title=menemukan _pemimpin_kompeten
} 
kata dasar "kudus" yang kata Ibraninya adalah "qadosy" atau "hagios" dalam bahasa Yunani, yang pada dasarnya berarti "pemisahan" - baik pemisahan dari hal-hal yang tidak kudus, maupun pemisahan ke arah halhal yang rohani. ${ }^{22}$ Kita diminta untuk menjadi "penurut-penurut Allah" seperti anak-anak yang kecil (Epesus 5:1). Untuk itu "seperti Dia yang kudus yang telah memanggil kamu, biarlah kamu menjadi kudus di dalam seluruh hidupmu (penerapan cara hidup); sebab ada tertulis, kuduslah kamu, sebab Aku kudus" (1 Petrus 1:15-16; Imamat 1l:44).

Kekudusan merupakan bagian utama dari kepribadian Allah. Hal ini harus menjadi sebuah landasan bagi setiap orang yang mau menjadi "penurut-penurut Allah." Jika seorang pemimpin melakukan hal ini, ia akan menjadi pewaris dalam kekudusanNya, yaitu pada saat ia dijamin oleh sifat dasarNya (Ibrani 12:10; 2 Petrus 1:4). Firman Allah berkata, tanpa kekudusan dalam hidup ini, tak seorangpun dapat "melihat Tuhan" (Ibrani 12:14). Tanpa kekudusan tak seorangpun mampu melihat Allah dan berhubungan denganNya secara pribadi.

Apa yang dapat dipakai untuk melihat kekudusan seseorang? Ukurannya ialah makin tinggi kerohanian seseorang, makin mudah ia mengaku dosa dan kesalahannya, dan sedia menyelesaikannya. Luther yang dikutip oleh Octavianus mengatakan, bahwa: "orang yang mudah mengaku dosa, juga mudah menerima pengampunan. Dan orang yang mudah menerima pengampunan mendapatkan juga kegembiraan." ${ }^{23}$

Kekudusan terjadi oleh karena seseorang hidup hari lepas hari di bawah anugerah salib Kristus. Ia bersedia mengaku salah kalau ia memang salah. Hal ini nampak tidak hanya dalam persekutuan, lembaga, atau gereja yang ia pimpin, melainkan juga dalam rumah tangganya sendiri. Anakanaknya sendiri akan menemukan kekudusannya oleh karena ia hidup di bawah anugerah Kristus.

Selain daripada itu, kekudusan juga menuntut kesediaan untuk berjalan dalam terang ilahi setiap hari yang akan menuntun kepada kepribadian dengan kewibawaan rohani yang jelas. ${ }^{24}$ Rasul Paulus, mengatakan: “...karena kita sekarang memiliki janji-janji itu, marilah kita menyucikan diri kita dari semua pencemaran jasmani dan rohani, dan dengan demikian menyempurnakan kekudusan kita ..." (2 Korintus 7:1).

Pemimpin yang berintegritas adalah pemimpin yang terus menjaga kekudusan hidupnya.

${ }^{22}$ William L. Holladay, A Concise Hebrew and Aramaic Lexicon of the Old Testament. s.v. "qadosy" (Grand Rapids, Michigan: Wm. B. Eerdmans, 1971); Joseph Henry Thayer, The New Thayer's Greek - English Lexicon of the New Testament. s.v. "hagios" Peabody, Massachusetts, 1981); Ensiklopedi Alkitab Masa Kini. s.v. "kudus" (Jakarta: Yayasan Komunikasi Bina Kasih/OMF, 1992).

${ }^{23}$ Ibid,

${ }^{24}$ Petrus Octavianus, Manajemen dan Kepemimpinan Menurut Wahyu Allah .( Malang: YPPII dan Gandum Mas, 1986), 103. 


\section{Pemimpin yang Hidup Dalam Ketulusan}

Pada waktu Paulus, mengatakan, "Usahakanlah supaya engkau layak di hadapan Allah sebagai seorang pekerja yang tidak usah malu, yang berterus terang memberitakan perkataan kebenaran itu" (2 Timotius 2:15), yang dimaksudkan dengan kata-kata "yang berterus terang memberitakan perkataan kebenaran itu" adalah sikap yang tulus atau ketulusan. Bahwa persyaratan lain yang tak kalah pentingnya bagi seorang pemimpin yang dapat dipercayai adalah hidup dalam ketulusan.

Harus diperhatikan bahwa pemimpin yang tulus tidak harus mengiklankan fakta. Pemimpin yang tulus akan kelihatan dalam segala hal yang dilakukan dan akan segera diketahui oleh setiap orang secara umum. Demikian pula, ketidaktulusan tidak dapat disembunyikan, disamarkan, atau ditutup-tutupi, tidak peduli secakap apapun seorang pemimpin dalam hal-hal lainnya.

Gen Ronald R. Fogleman mengatakan: "Ketulusan adalah perilaku tanpa kepura-puraan dan kesan yang palsu. Pemimpin yang berintegritas bersikap tulus - tindakan mereka sesuai dengan perkataannya." 25 A.B. Susanto, mengatakan, "Seorang pemimpin harus secara tulus selalu mau melihat dirinya sendiri dan menelaah kembali apakah pola kepemimpinannya benar-benar dilandasi oleh teladan Yesus ..."

Pemimpin yang berintegritas selalu menyesuaikan perkataannya dengan tindakannya. Itulah yang membuatnya menjadi seorang pemimpin yang hebat dan dipercayai. Pemimpin seperti ini tahu bahwa waktu akan membuktikan bahwa ia benar dan ia akan bersedia untuk menunggu. Ia sangat yakin bahwa orang lain pasti mempercayai dan mengikutinya.

\section{Pemimpin yang Memiliki Konsistensi}

Dalam 2 Timotius 2:3-6 Paulus mengatakan, demikian:

Ikutlah menderita sebagai seorang prajurit yang baik dari Kristus Yesus. Seorang prajurit yang sedang berjuang tidak memusingkan dirinya dengan soal-soal penghidupannya, supaya dengan demikian ia berkenan kepada komandannya. Seorang olahragawan hanya dapat memperoleh mahkota sebagai juara, apabila ia bertanding menurut peraturanperaturan olahraga. Seorang petani yang bekerja keras haruslah yang pertama menikmati hasil usahanya.

Dengan illustrasi-illustrasi yang sederhana, di mana Paulus menyebut "prajurit", "olahragawan", dan "petani," Paulus bermaksud menekankan apa

\footnotetext{
${ }^{25}$ Gen. Ronald R. Fogleman, "Kaitan Integritas dan Kepemiminan,” lead.sabda.org; diakses $22 \quad$ Oktober $2007 ; \quad$ tersedia di http://www.lead.sabda.org/?title=kaitan_dan_kepemimpinan

${ }^{26}$ A.B. Susanto, Meneladani Jejak Yesus Sebagai Pemimpin. (Jakarta: PT Grasindo, 1997), 32.
} 
yang disebut "konsistensi." Bahwa seorang pemimpin haruslah memiliki konsistensi.

Fred Smith, mengatakan: "Pada dasarnya, para anggota suatu kelompok ingin menjadi rekan kerja bagi pemimpinnya, tetapi mereka harus mengetahui bagaimana melakukannya. Sikap konsisten dari pemimpinnyalah yang menjadi jawabannya." ${ }^{27}$

Seorang pemimpin yang tidak bersikap konsisten dapat membingungkan anggotanya. Selanjutnya Smith, mengatakan: "Hal ini dapat menciptakan sebuah kepemimpinan yang kosong ketika orang-orang yang agresif berjalan sendiri sementara sebagian besar anggota menjadi lumpuh, karena tidak tahu apa yang harus dilakukan dan takut melakukan kesalahan." 28

Pada waktu mengomentari masalah konsistensi, Gen Ronald R. Fogleman, mengatakan:

Satu perbuatan nyata yang mencerminkan integritas akan meninggalkan kesan, namun perilaku seorang pemimpin haruslah konsisten jika ia ingin berhasil membentuk suatu organisasi. Pada kenyataannya, integritas bersifat imperatif karena secuil pelanggaran saja terhadap integritas akan dapat meninggalkan cacat permanen. Para pemimpin haruslah konsisten dalam menjalankan standar kedisiplinan. ${ }^{29}$

Dalam 2 Timotius 4:1-4, Paulus, dalam "pandangan kenabiannya", menyampaikan kepada Timotius tentang situasi yang akan datang, yang akan dihadapinya, katanya:

Di hadapan Allah dan Kristus Yesus yang akan menghakimi orang yang hidup dan yang mati, aku berpesan dengan sungguh-sungguh kepadamu demi penyataan-Nya dan demi Kerajaan-Nya: Beritakanlah firman, siap sedialah baik atau tidak baik waktunya, nyatakanlah apa yang salah, tegorlah dan nasihatilah dengan segala kesabaran dan pengajaran. Karena akan datang waktunya, orang tidak dapat lagi menerima ajaran sehat, tetapi mereka akan mengumpulkan guru-guru menurut kehendaknya untuk memuaskan keinginan telinganya. Mereka akan memalingkan telinganya dari kebenaran dan membukanya bagi dongeng. Dalam situasi seperti itu, bagaimana seharusnya dan apa yang perlu Timotius kerjakan. Ayat lima menjawabnya, demikian: "Tetapi kuasailah dirimu dalam segala hal, sabarlah menderita, lakukanlah pekerjaan pemberita Injil dan tunaikanlah tugas pelayananmu."

Sehubungan dengan masalah konsistensi ini, David Hocking, mengatakan: "Para pemimpin rohani harus memiliki suatu kesaksian dan

\footnotetext{
27 Fred Smith, Memimpin Dengan Integritas. (Jakarta: YPI Immanuel, 2002), 163.

${ }^{28}$ Ibid,

${ }^{29}$ Gen. Ronald R. Fogleman, "Kaitan Integritas dan Kepemiminan," lead.sabda.org; $\begin{array}{lllll}\text { diakses } & 22 & \text { Oktober } & 2007 ; & \text { tersedia }\end{array}$ http://www.lead.sabda.org/?title=kaitan_dan_kepemimpinan
} 
gaya hidup yang konsisten di antara orang-orang yang tidak percaya maupun mereka yang percaya." 30 Senada dengan itu, Robert L. Peterson dan Alexander Strauch, dalam buku mereka yang berjudul, "Kepemimpinan Agape," mengatakan:

Suatu bagian utama dalam tugas penggembalaan, dan yang sering menjadi cobaan, adalah menyelesaikan masalah dosa seseorang. Kasih Agape tidak mengabaikan dosa, karena kasih tidak harus terpisah dari kesucian dan keadilan. Oleh karena itu, ketika seorang anggota gereja hidup dalam dosa dan tidak mau bertobat, menolak bimbingan dan pertolongan, gereja harus bertindak dengan memberikan disiplin. ${ }^{31}$

Dalam pelayanannya, seorang hamba Tuhan yang bernama: R.C. Chapman menemukan ketidakpuasan ketika masalah dosa dan tidak mau bertobat sering menimbulkan perpisahan dalam gereja. Lalu apa yang dia lakukan? "Dia terus berdoa bagi orang yang tersinggung, menginginkan kembalinya seseorang ke dalam persekutuan. Di dalam penyelesaian dosa dengan orang lain, dia sangat berhati-hati." 32

Secara alami, tanggapan manusia karena penghinaan atau ejekan adalah marah, balas dendam, sikap membenarkan diri sendiri, atau pengunduran diri. Tetapi tanggapan orang-orang yang berintegritas berbeda: mereka bertindak seperti Kristus, yang lemah lembut dan suka mengampuni. Dengan mengutip kata-kata Peterson dan Strauch ${ }^{33}$, penulis, mengatakan: Kita sulit membayangkan apa yang Allah akan lakukan ketika hamba-hambaNya sungguh-sungguh mengasihi seperti Kristus mengasih.

Konsistensi merupakan suatu keharusan bagi seorang pemimpin yang berintegritas. Martyn Lloyd-Jones pernah membuat pengamatan yang sangat berarti tentang kehidupan para pemimpin yang memiliki konsistensi dan menuliskannya, demikian:

Saya menantang Anda untuk membaca kehidupan setiap orang kudus yang pernah mengagungkan kehidupan gereja tanpa melihat seketika bahwa karakter yang terutama dalam hidup orang tersebut adalah disiplin dan peraturan. Memang selalu demikian, itulah karakter universal semua pria dan wanita ternama yang taat kepada Allah ... Jelas sekali itu adalah sesuatu yang sangat alkitabiah dan mutlak sangat penting. ${ }^{34}$

R.C. Chapman yang menjadi contoh dalam hal konsistensi, oleh Peterson dan Strauch, ditulis demikian:

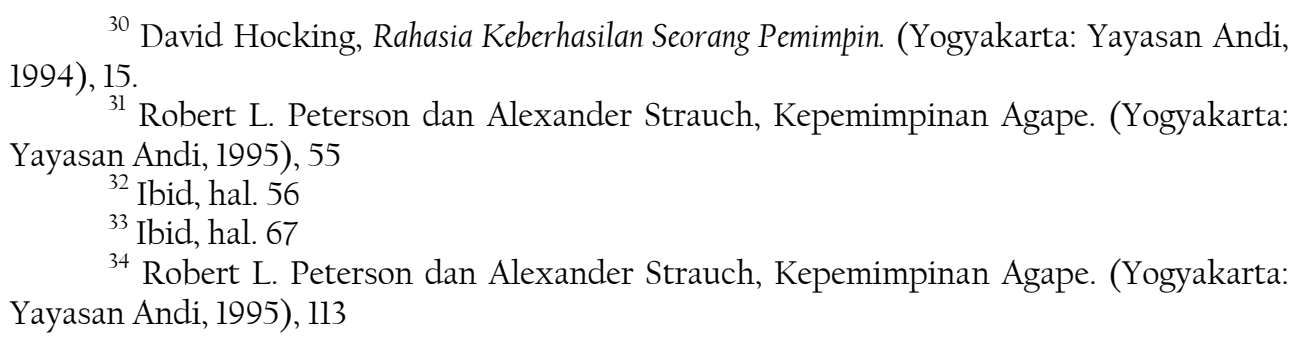

${ }^{30}$ David Hocking, Rahasia Keberhasilan Seorang Pemimpin. (Yogyakarta: Yayasan Andi,

${ }^{31}$ Robert L. Peterson dan Alexander Strauch, Kepemimpinan Agape. (Yogyakarta: Yayasan Andi, 1995), 55

${ }^{32}$ Ibid, hal. 56

${ }^{33}$ Ibid, hal. 67

${ }^{34}$ Robert L. Peterson dan Alexander Strauch, Kepemimpinan Agape. (Yogyakarta: Yayasan Andi, 1995), 113 
Pada awal pelayanannya, Chapman menyadari kebutuhan penting untuk tidak mengalami kegagalan dalam komitmennya pada penguasaan diri secara pribadi. Dia melihat nilai itu besar dalam pikiran, tubuh dan rohnya. Dia melihat kebutuhan yang sangat vital bagi penyegaran rohani maupun jasmani, yang juga menjadi salah satu sebab mengapa ia menyediakan rumah istirahat bagi para pekerja kristen. Kehidupan pribadinya menjadi suatu teladan dari kehidupan kristen berdisiplin yang menghasilkan buah roh. ${ }^{35}$

Paulus menasihatkan Timotius supaya menjadi teladan dalam perkataan, tingkah laku, kasih, kesetiaan dan kesucian atau kekudusan (1 Timotius 4:12). Ralph M. Rigs mengatakan:

Kekurangan terbesar dewasa ini ialah pemimpin yang dapat memberikan teladan. Seorang pengajar dan pemimpin seharusnya mampu menjadi teladan. Kedudukan seorang gembala meliputi kewajiban untuk lebih matang, lebih rohani, lebih setia, lebih bertekun dalam doa dan lebih saleh daripada anggota jemaatnya." 36

Pikiran yang sama dikemukakan oleh Derek J. Tidball dalam tulisannya yang mengatakan:

Sesungguhnya kuasa teladan masih tetap merupakan salah satu pengaruh yang paling kuat dalam kehidupan manusia dan sangat penting bagi pekerjaan gembala jemaat. Keteladanan moral dan rohani jauh lebih penting daripada karunia berkhotbah, kemampuan administrasi atau prestasi akademis. ${ }^{37}$

Keteladanan seorang pemimpin mempunyai dampak yang besar dalam jemaat. Penekanan ini disampaikan oleh Frederik K.C. Price dengan mengatakan:

Seorang pemimpin jemaat harus menjadi teladan kepada orang-orang yang ditempatkan Allah di bawah pengawasannya. Jika pemimpin men jadi teladan dalam segala hal yang diperbuatnya maka kemungkinan besar akibatnya ialah jemaat akan mencontohi kehidupannya. Karena secara moral apapun yang dijumpai dalam jemaat berasal dari gembalanya. ${ }^{38}$

Seorang pemimpin yang konsisten dalam pelayanannya akan menjadi teladan bagi semua orang yang dipimpinnya.

\section{Pemimpin yang Memiliki Keteguhan Hati}

Dalam 2 Timotius 2:9-10 Paulus menuliskan, demikian:

\footnotetext{
${ }^{35}$ Ibid, hal. 113-114

${ }^{36}$ Ralph M. Rigs, Gembala Sidang Yang Berhasil. (Malang: Gandum Mas, n.d.), 67

${ }^{37}$ Derek J. Tidball, Teologi Penggembalaan. (Malang: Gandum Mas, 1995), 125

38 Frederik K.C. Price, Saran-saran Praktis untuk Pelayanan Yang Berhasil. (Jakarta: Yayasan Pekabaran Injil Immanuel, 1993), 36
} 
Karena pemberitaan Injil inilah aku menderita, malah dibelenggu seperti seorang penjahat, tetapi firman Allah tidak terbelenggu. Karena itu aku sabar menanggung semuanya itu bagi orang-orang pilihan Allah, supaya mereka juga mendapat keselamatan dalam Kristus Yesus dengan kemuliaan yang kekal.

Dalam ayat-ayat ini Paulus menekankan tentang apa yang disebut "keteguhan hati." Pendiri dan pemimpin World MAP dan editor pada majalah World Digest dan majalah ACTS, Ralph Mahoney, mengatakan: "Allah mencari orang-orang yang dapat diangkatNya menjadi pemimpin, " 39 yaitu pemimpin yang memiliki keteguhan hati.

Pada bagian lain, Rasul Paulus, yang akan segera menemui ajalnya, mengingatkan Timotius:

Ketahuilah bahwa pada hari-hari terakhir akan datang masa yang sukar. Manusia akan mencintai dirinya sendiri dan menjadi hamba uang. Mereka akan membual dan menyombongkan diri, mereka akan menjadi pemfitnah, mereka akan berontak terhadap orang tua dan tidak tahu berterima kasih, tidak mempedulikan agama, tidak tahu mengasihi, tidak mau berdamai, suka menjelekkan orang, tidak dapat mengekang diri, garang, tidak suka yang baik, suka mengkhianat, tidak berpikir panjang, berlagak tahu, lebih menuruti hawa nafsu dari pada menuruti Allah. Secara lahiriah mereka menjalankan ibadah mereka, tetapi pada hakekatnya mereka memungkiri kekuatannya. Jauhilah mereka itu! Sebab di antara mereka terdapat orang-orang yang menyelundup ke rumah orang lain dan menjerat perempuan-perempuan lemah yang sarat dengan dosa dan dikuasai oleh berbagai-bagai nafsu, yang walaupun selalu ingin diajar, namun tidak pernah dapat mengenal kebenaran. Sama seperti Yanes dan Yambres menentang Musa, demikian juga mereka menentang kebenaran. Akal mereka bobrok dan iman mereka tidak tahan uji. Tetapi sudah pasti mereka tidak akan lebih maju, karena seperti dalam hal Yanes dan Yambres, kebodohan mereka pun akan nyata bagi semua orang (2 Timotius 3:1-9).

Hal ini dapat dengan mudah menciutkan nyali seorang yang terpanggil menjadi pemimpin sehingga menjadi bimbang dan putusasa. Menghadapi hal ini, Rasul Paulus mengatakan kepada Timotius, demikian:

Tetapi engkau telah mengikuti ajaranku, cara hidupku, pendirianku, imanku, kesabaranku, kasihku dan ketekunanku. Engkau telah ikut menderita penganiayaan dan sengsara seperti yang telah kuderita di Antiokhia dan di Ikonium dan di Listra. Semua penganiayaan itu kuderita dan Tuhan telah melepaskan aku dari padanya. Memang setiap orang yang mau hidup beribadah di dalam Kristus Yesus akan menderita aniaya, sedangkan orang jahat dan penipu akan bertambah jahat, mereka

\footnotetext{
${ }^{39}$ Ralph Mahoney, Pembentukan Seorang Pemimpin. (Glenoaks, Burbank, USA: World Missionary Assistance Plan, n.d.), 88
} 
menyesatkan dan disesatkan. Tetapi hendaklah engkau tetap berpegang pada kebenaran yang telah engkau terima dan engkau yakini, dengan selalu mengingat orang yang telah mengajarkannya kepadamu (2 Timotius 3:10-14).

Yang Paulus maksudkan di sini ialah bahwa pemimpin yang berintegritas, yang dapat dipercayai akan tetap teguh hatinya, walaupun ia mengalami tantangan dalam pelayanannya, bahkan tantangan yang hebat sekalipun. Contoh pemimpin yang seperti ini dapat ditemukan dalam diri seorang yang bernama Yusuf di dalam Perjanjian lama.

"Sepuluh atau dua belas tahun di dalam penjara dengan rantai pada pergelangan tangan dan kalung besi di sekitar leher dapat menghancurkan hidup siapapun." ${ }^{40}$ Yusuf, anak Yakub dari Rahel, berada dalam struktur keadaan yang direncanakan oleh arsitek Ilahi. Namun tanpa memiliki pengetahuan yang pasti tentang hal ini membuat hidupnya nampak tak berpengharapan. Kalau saja ia tahu hal ini dengan pasti, boleh jadi kesusahan dan masa menunggu masih dapat ia tolerir.

Apa yang Yusuf miliki hanyalah sebuah mimpi yang menunjukkan bahwa ia akan menderita penolakan dari saudara-saudaranya dan akan dilemparkan ke dalam sumur (Kejadian 37:5-7). Tak ada petunjuk dalam pernyataan dari Tuhan bahwa ia akan dijual sebagai budak, difitnah, dan melewatkan waktunya bertahun-tahun di dalam penjara. Tentunya Yusuf berpikir-pikir, "Apa yang sedang terjadi? Mengapa semua hal ini terjadi padaku?"

Ketika martir pertama, Stefanus, memberikan pembelaannya sebelum ia mati, ia mengemukakan juga tentang kesengsaraan Yusuf. "Allah ... melepaskannya dari segala penindasan ..." (Kisah Para Rasul 7:10). Ya, Yusuf mengalami penindasan! Penindasan yang tak dapat dilukiskan (Kejadian 39:20).

Yusuf tidak melakukan sesuatu hal yang salah di rumahnya ataupun di rumah Potifar. Namun ia menjadi budak yang dipenjarakan tanpa harapan untuk dapat dikeluarkan. ${ }^{41}$ Ia justru mempertahankan kekudusan dan kemurnian moral (Kejadian 39:7-12). Upahnya adalah hukuman seumur hidup tanpa grasi/janji apapun, di penjara bawah tanah yang panas, penuh kutu, penuh kotoran dan berbau busuk. ${ }^{42}$

Kebanyakan orang tidak pernah memikirkan lebih jauh akan penderitaan yang dirasakan oleh Yusuf dalam tahun-tahun ia terasing dan kesepian itu. Barangkali makanannya hanyalah bubur, dan pemuas dahaganya hanyalah air yang berasal dari sungai Nil yang kotor itu. Yusuf

\footnotetext{
${ }^{40}$ Ralph Mahoney, Pembentukan Seorang Pemimpin. (Glenoaks, Burbank, USA: World Missionary Assistance Plan, n.d.), 84

${ }^{41}$ Bandingkan dengan Kejadian 39:20-23 dan 40:2-3.

${ }^{42}$ Ensiklopedi Alkitab Masa Kini, Jl. 2. s.v. "Penjara." (Jakarta: Yayasan Komunikasi Bina Kasih/OMF, 1996).
} 
adalah korban dari pengerjaan dan persiapan Tuhan. Sehubungan dengan ini, Ralph Mahoney, menulis:

... proses dengan mana Allah memakai kesulitan-kesulitan yang kita alami untuk membuktikan dan menguji FirmanNya yang memberi petunjuk dan pengarahan kepada kita. Melalui dapur penderitaan kita bergerak maju dari "orang yang dipanggil" menjadi "orang yang dipilih." Pengujian seperti itu perlu karena mempersiapkan kita untuk menghadapi peperangan rohani yang dahsyat yang akan kita alami dalam kepemimpinan rohani. ${ }^{43}$

Perubahan dari kesulitan-kesulitan dalam penjara ke tempat tanggung jawabnya yang baru dapat dengan mudah menimbulkan suatu kesombongan dalam diri Yusuf, karena menjadi orang penting dan terutama. Tetapi Allah telah mengerjakan kerendahan hati di dalam diri Yusuf di liang tutupan penjara itu, dan hal ini menyelamatkannya dari jerat kesombongan. Penulis sangat setuju dengan apa yang dikatakan oleh Gen Ronald R. Fogleman, bahwa: "Untuk menjadi seorang pemimpin, anda harus memiliki lebih dari sekedar citra diri (image) yang berintegritas Anda harus memiliki keteguhan hari." ${ }^{44}$

\section{Pemimpin yang Mampu Bertahan Sampai Akhir}

Dalam 2 Timotius 2:22 Paulus mengatakan, "Sebab itu jauhilah nafsu orang muda, kejarlah keadilan, kesetiaan, kasih dan damai bersama-sama dengan mereka yang berseru kepada Tuhan dengan hati yang murni." Salah satu hal yang ditekankan oleh Paulus dalam ayat ini adalah "kejarlah ... kesetiaan" yang dapat berarti bertahan sampai akhir. Seorang pemimpin tidak saja harus memulai tugasnya dengan baik, tetapi ia harus mengerjakannya dengan baik pula sampai akhir.

Seorang pemimpin dapat menunjukkan integritasnya dengan melaksanakan tugasnya sebaik mungkin, terlepas dari seberapa penting tugas itu atau siapa yang akan mendapatkan pujian kelak. A.B. Susanto, mengatakan:

Integritas diri seorang pemimpin juga terlihat dari kesetiaannya terhadap tugas dan tanggung jawab sekalipun pekerjaan yang dihadapi kecil adanya, karena dengan kesetiaannya terhadap perkara-perkara yang kecil akan membuat ia mampu pula untuk melaksanakan perkaraperkara yang besar. Ini merupakan ajaran Yesus sebagaimana yang tertera dalam Lukas 16:10-12, yang selanjutnya juga mengingatkan kita

\footnotetext{
${ }^{43}$ Ralph Mahoney, Pembentukan Seorang Pemimpin. (Glenoaks, Burbank, USA: World Missionary Assistance Plan, n.d.), 89

${ }^{44}$ Gen. Ronald R. Fogleman, "Kaitan Integritas dan Kepemiminan,” lead.sabda.org; diakses $22 \quad$ Oktober $\quad 2007 ; \quad$ tersedia http://www.lead.sabda.org/?title=kaitan_dan_kepemimpinan
} 
agar selalu setia dan bertanggung jawab dalam mengurus harta orang lain supaya kita memiliki hak atas pekerjaan yang kita lakukan itu. ${ }^{45}$

Pada saat berbicara tentang orang-orang sukses, dalam sebuah tulisannya, Joni Liu mengajukan sebuah pertanyaan retorika, katanya:

Dari manakah lahirnya orang-orang sukses? Apakah seseorang yang sukses berasal dari keluarga yang mapan? Belum tentu! Jadi apakah seseorang yang sukses berasal dari keluarga yang miskin dan dia berjuang sehingga dia menjadi sukses? Jawabannya juga belum tentu! Namun salah satu kunci sukses yang paling mendasar yang diterapkan oleh berbagai orang yang sudah sukses adalah nilai sebuah konsistensi. ${ }^{46}$

Pemimpin-pemimpin yang sukses adalah pemimpin-pemimpin yang konsisten dalam melaksanakan kegiatannya. Seorang guru musik yang secara konsisten dalam satu minggu mengajar musik kepada 5 orang, dalam satu bulan ia pasti mengajar musik kepada 20 orang. Seorang Gembala Sidang yang membimbing 3 orang dalam setiap minggunya, dalam satu bulan dia pasti sudah membimbing 12 orang anggota. Seorang mahasiswa yang secara konsisten terus belajar, seiring dengan waktu pasti akan dapat menyelesaikan kuliahnya dengan baik.

Kekuatan melakukan sesuatu secara konsisten ini bukan saja menjadikan seseorang menjadi seorang yang ahli dan profesional di bidangnya, tetapi juga menjadikannya seorang yang dapat dipercayai. Karya dan kerja yang dibangun dengan proses konsistensi ini tidak mudah digoyang apabila dihadapkan dengan berbagai cobaan. Karena pondasi yang dibangun begitu kokoh dan terus dipupuk seiring dengan waktu yang berlalu. $^{47}$

Seorang pemimpin yang berintegritas akan mulai menetapkan impian dan tujuan yang akan dicapai, kemudian membentuk kebiasaan-kebiasaan yang akan mengarahkannya pada hasil yang ingin dicapai. Ia akan konsisten pada setiap kegiatan kecil yang ia rencanakan untuk mencapai impian tersebut. Maka pada suatu saat, impian tersebut pasti akan berada di tangannya. Peter Drucker yang dikutip oleh John Maxwell, mengatakan: "Tindakan seorang pemimpin dan kepercayaan yang dipegang oleh pemimpin harus sama atau paling sedikit serasi. Kepemimpinan yang efektif ... tidak berdasarkan sifat pintar; ini terutama berdasarkan sikap konsisten." ${ }^{48}$

Dalam satu bagian Firman Tuhan dikatakan, "Sesungguhnya kami menyebut mereka berbahagia, yaitu mereka yang telah bertekun ..."

\footnotetext{
${ }^{45}$ A.B Susanto, Meneladani Jejak Yesus Sebagai Pemimpin. (Jakarta: PT Grasindo, 1997) 11

${ }^{46}$ Joni Liu, "Nilai Sebuah Konsistensi." Pembelajar.com, diakses tanggal 5 Oktober 2007, tersedia di http: //www.pembelajar.com/wmview.php?ArtID=739\&\&term=joni+liu

47 Joni Liu, "Nilai Sebuah Konsistensi." Pembelajar.com, diakses tanggal 5 Oktober 2007, tersedia di http: //www.pembelajar.com/wmview.php?ArtID=739\&term=joni+liu

${ }^{48}$ John C. Maxwell, Mengembangkan Kepemimpinan di Dalam Diri Anda. (Jakarta: Binarupa Aksara, 1995), 46-47.
} 
(Yakobus 5:11). Senada dengan itu, Robert D. Hales, mengatakan, "Kita tidak dapat berharap untuk bisa belajar bertahan dalam usia senja kita, jika kita telah mengembangkan kebiasaan untuk menyerah ketika hal-hal menjadi sulit sekarang." ${ }^{49}$

Contoh-contoh dari sikap bertahan sampai akhir diajarkan oleh para nabi sewaktu mereka memperlihatkan keberanian sementara menghadapi ujian dan penderitaan untuk melaksanakan kehendak Allah. Teladan yang terbaik dalam hal ini berasal dari kehidupan Yesus Kristus. Ketika Dia menderita di kayu salib di bukit Kalvari, Yesus merasakan kesepian sampai Ia berdoa kepada BapaNya di Sorga, "Mengapa Engkau meninggalkan Aku?" (Matius 27:46). Yesus mengetahui siapa DiriNya - Putra Allah. Dia mengetahui tujuanNya untuk melaksanakan kehendak Bapa melalui Korban Tebusan. Dia dapat saja memanggil pasukan malaekat untuk menurunkan Dia dari salib, tetapi Ia dengan setia bertahan sampai akhir dan menyelesaikan tujuan untuk apa Dia telah datang ke bumi.

Sangatlah menyentuh hati penulis bahwa di kemudian hari, ketika Bapa memperkenalkan PutraNya, Ia berkata, "Inilah Anak yang Kukasihi, kepada-Nyalah Aku berkenan" (2 Petrus 1:17).

Kondisi dan situasi sekarang ini dan yang akan datang, menjadi tantangan tersendiri bagi para pemimpin, tetapi para pemimpin yang baik akan setia menanggung pertentangan, pencobaan, dan kesengsaraan dalam kehidupan mereka, dan dalam melakukannya, bukan saja diperkuat secara pribadi melalui pengalaman mereka, tetapi mereka juga memperkuat orangorang di sekitar mereka melalui teladan mereka. ${ }^{50}$

Bertahan sampai akhir adalah lebih dari sekedar bertahan dan menunggu sampai akhirnya ajal menjemput. Robert D. Hales, menulis, "Untuk bertahan sampai akhir dibutuhkan iman yang kuat. Di taman Getsemani, Yesus ‘sujud dan berdoa, kataNya, Ya BapaKu, jikalau sekiranya mungkin, biarlah cawan ini lalu dari padaKu, tetapi janganlah seperti yang Kukehendaki, melainkan seperti yang Engkau kehendaki"' (Matius 26:39). ${ }^{51}$ Diperlukan iman yang kuat, yaitu iman untuk percaya kepada Tuhan yang akan mendatangkan kekuatan yang besar.

Seorang pemimpin akan terus mengembangkan kesabaran dalam mengatasi cobaan dan kesengsaraan yang mungkin akan menimpanya. Dia harus rendah hati untuk mempelajari ketrampilan baru dan memiliki ketetapan hati untuk bertahan sampai akhir. Tidak perduli apa yang harus dikorbankannya untuk mencapai tujuannya. Alkitab berkata bahwa

\footnotetext{
${ }^{49}$ Robert D. Hales, "Bertekun Sampai Akhir," lds.org, diakses tanggal 3 Nopember 2007, tersedia di http://www.lds.org/conference/talk/display/0,5232,23-11-70-28,00 html

50 Bandingkan dengan kesaksian-kesaksian yang tertulis dalam buku, Batu-Batu Tersembunyi Dalam Pondasi Kita. (Surabaya: Yayasan Kasih Dalam Perbuatan, 2001).

${ }^{51}$ Robert D. Hales, "Bertekun Sampai Akhir," lds.org, diakses tanggal 3 Nopember 2007, tersedia di http://www.lds.org/conference/talk/display/0,5232,23-11-70-28,00 html
} 
kepada pemimpin seperti itu akan dibrikan "mahkota kebenaran" (2 Timotius 4:8).

\section{Pemimpin yang Cakap Mengajar}

Dalam 2 Timotius 2:2 dikatakan demikian, "Apa yang telah engkau dengar dari padaku di depan banyak saksi, percayakanlah itu kepada orangorang yang dapat dipercayai, yang juga cakap mengajar orang lain." ${ }^{2}$ Dalam ayat ini Paulus menekankan bahwa seorang pemimpin, bukan saja seorang yang dapat dipercayai, tetapi juga haruslah seorang yang cakap mengajar orang lain. Penekanan ini diulangi lagi dalam ayat 24, yang mengatakan, “...seorang hamba Tuhan ...harus cakap mengajar...” Tujuannya ialah supaya mandat yang disampaikan, yaitu Injil Kristus, tidak dikurangi dan tidak ditambahkan. John Wesley Brill, mengatakan, "Yang dikehendaki Paulus ialah supaya Injil disampaikan dari orang yang setia kepada orang lain yang juga setia, bagaikan sebuah rantai yang tak ada akhirnya." 53

Pada waktu Tuhan Yesus menyuruh kesebelas orang yang selalu mengikutiNya selama Ia di dalam dunia ini, untuk pergi ke seluruh muka bumi dan menjadikan semua bangsa muridNya, Ia berkata kepada mereka agar mereka mengajar murid-murid yang baru itu melakukan sesuatu yang telah diperintahkanNya kepada mereka. ${ }^{54}$

Dr. Bill Bright mengatakan, di dalam proses berinteraksi dan memberi bimbingan kepada ribuan mahasiswa, kaum awam dan pendeta selama bertahun-tahun sejak tahun 1951, kami menemukan bahwa banyak anggota gereja (termasuk anggota-anggota gereja yang mengagungkan Tuhan seperti kita dan dengan setia mengajarkan firmanNya) tidak yakin akan keselamatan mereka. Banyak orang kristen hidup dalam kekalahan dan kegagalan, dan banyak orang kristen tidak tahu bagaimana menyaksikan iman mereka secara efektif. ${ }^{55}$

Dalam rangka menanggulangi kebutuhan seperti yang disebutkan di atas, diperlukan

pemimpin, yang selain harus dapat dipercayai, juga harus cakap mengajar orang lain. Dengan kata lain, diperlukan pemimpin yang memiliki kapabilitas dalam mengajar orang lain.

Dalam Alkitab ditemukan bahwa pada dasarnya Allah menetapkan pemimpin untuk memimpin, diteguhkan dengan kapabilitas untuk memimpin. Kapabilitas itu melibatkan berbagai unsur penting yang berperan dalam menjadikan seorang pemimpin menjadi pemimpin yang

\footnotetext{
${ }^{52}$ Huruf tebal ditambahkan oleh penulis.

53 John Wesley Brill, Tafsiran Surat Timotius dan Titus. (Bandung: Kalam Hidup, 1978), 73.

${ }_{55}^{54}$ Bandingkan dengan Matius 28:20

55 Bill Bright, "Konsep Yang Dapat Ditawarkan," jesuswho.org, diakses tanggal 4 Nopember 2007, tersedia di http://www.jesuswho.org/indonesian/tc/whatis.htm
} 
berbobot, kuat, cakap dan trampil dalam memimpin.Yakob Tomatala, mengatakan:

Kapabilitas merupakan unsur dinamis dari kapasitas berupa kemampuan atau kesanggupan untuk berbuat. Kesanggupan seperti ini dapat disebut sebagai kecakapan atau keahlian khas yang dapat memberi kemampuan untuk memimpin/menggerakkan orang ke arah tujuan yang telah dicanangkan yang dapat diwujudkan dengan kinerja tinggi. ${ }^{56}$

Untuk menjadi pemimpin yang cakap atau yang kapabel, beberapa prinsip dalam 2 Timotius 2 akan dijelaskan berikut ini.

\section{Belajar Dengan Tekun}

Firman Allah dalam 2 Timotius 2:15 mengatakan, demikian, "Usahakanlah supaya engkau layak di hadapan Allah sebagai seorang pekerja yang tidak usah malu, yang berterus terang memberitakan perkataan kebenaran itu."

Seorang pemimpin ditunjuk dan ditetapkan oleh Allah untuk memimpin. ${ }^{57}$ Bahkan menurut Leroy Eims, bahwa "Seorang pemimpin harus memimpin. Dan untuk memimpin, ia harus mengetahui pekerjaannya." 58 Untuk menjawab kebutuhan ini, harus ada sesuatu yang mesti dilakukan oleh seorang pemimpin. Dan hal itu adalah belajar dengan tekun, yang di dalam 2 Timotius 2:15 digunakan kata "usahakanlah." Jika hal ini dilakukan, maka "Tuhan akan membri kepadamu pengertian dalam segala sesuatu" (2 Timotius 2:7).

Ketika berbicara tentang bagaimana mewujudkan masa depan bangsa yang gemilang di mana salah satu penekanannya adalah sumber daya manusia (SDM), Elwin Tobing, menyebutkan tentang apa yang dilakukan oleh seorang konglomerat baja Amerika Serikat yang memberi perhatian besar terhadap peningkatan pengetahuan masyarakat Amerika, katanya:

Sangat mengagumkan contoh yang diberikan Andrew Carnegie, konglomerat baja AS yang membangun lebih kurang 1.800 perpustakaan di seluruh Amerika. Harapan Rakyat, pemimpin nasional hendaknya mampu menggalang sumberdaya pemerintah dan swasta untuk mendirikan dan mengembangkan perpustakaan umum di setiap ibukota kabupaten. Hanya dengan memperlengkapi rakyat dengan pengetahuan, bangsa Indonesia akan mampu mengikuti kemajuan peradaban manusia. ${ }^{59}$

${ }^{56}$ Yakob Tomatala, "Kepemimpinan Kristen dan Pengaruhnya di Abad XX1," Makalah: Reuni STTJ, Makassar, Juli 2001, 4

${ }^{57}$ Paul R. Van Gorder, "Pendeta Sebagai Seorang Pemimpin" dalam Warren W. Wiersbe, Paul R. Van Gorder, dan Howard F. Sugden, Prioritas Seorang Gembala. (Malang: Gandum Mas, n.d.), 32.

${ }_{58}^{58}$ Leroy Eims, 12 Ciri Kepemimpinan Yang Efektif. (Bandung: Kalam Hidup, n.d.), 157.

59 Elwin Tobing, "Seputar Kepemimpinan Nasional," theindonesianintitute.org; diakses $22 \quad$ Oktober 2007; $\quad$ tersedia di http://www.theindonesianinstitute.org/OurViewMarchl.htm 
Kalau orang-orang dunia ini melihat dan memahami betapa pentingnya belajar dengan tekun dalam upaya meningkatkan kemampuan pemimpinnya, betapa lagi mereka yang menjadi pemimpin-pemimpin gereja atau pemimpin-pemimpin rohani.

Sebagai seorang pemimpin yang bekerja dengan sungguh-sungguh harus mempunyai sasaran yang tidak boleh ditawar-tawar yaitu menuntun orang lain untuk tumbuh menjadi dewasa dalam Kristus. Nehemiah Mimery, mengatakan: "Bertumbuh menjadi dewasa dalam Kristus nampak dalam beberapa hal: merindukan makanan rohani yaitu Firman Tuhan, mempunyai hubungan yang erat dengan Tuhan, mempersembahkan apa yang dimiliki bagi Tuhan dan menjadi saksi-saksi Tuhan." ${ }^{60}$ Untuk dapat melaksanakan tugas dan tanggung jawab yang mulia ini, pemimpin harus memiliki kemampuan khusus, dan kemampuan itu hanya dapat diperoleh dengan jalan belajar dengan tekun.

Dalam 2 Timotius 2:15 yang mengatakan, "Usahakanlah supaya engkau layak di hadapan Allah sebagai seorang pekerja yang tidak usah malu, yang berterus terang memberitakan perkataan kebenaran itu," kata "usahakanlah" dalam versi King James tertulis study ${ }^{61}$ dan dalam versi The Amplified New Testament dipakai kata study and be eager ${ }^{62}$ yang dapat diartikan belajar dengan tekun dan sungguh-sungguh.

Setiap pemimpin harus berusaha agar dirinya layak di hadapan Allah. Itu berarti ia wajib berusaha agar ia didapati benar oleh Allah atau berkenan kepada Allah. Ia harus berusaha dengan sebaik mungkin untuk menjadi pekerja yang melakukan tugasnya dengan baik dan teliti. John Wesley Brill, mengatakan:

Pekerja yang bodoh, tidak setia, dan malas, tentu saja akan malu di hadapan Tuhan. Apa yang harus dilakukan agar ia tidak akan malu melaksanakan Firman Allah dengan sungguh-sungguh. Tugasnya bukanlah membuat suatu Injil yang baru, melainkan mengajarkan Injil yang murni yang dipercayakan kepadanya. Ia harus benar-benar mengerti akan keperluan tiap-tiap anggota jemaatnya, ia harus mengetahui bilamana ia patut memberi "susu" dan bilamana ia memberi "daging yang keras", ia harus tahu bilamana ia harus menegor mereka yang perlu ditegor dan menghibur yang perlu dihibur. Patutlah ia mengetahui bahwa Firman yang dibagikannya itu berfaedah bagi semua

\footnotetext{
${ }^{60}$ Nehemiah Mimery, Rahasia Tentang Penggembalaan Jemaat. (Mimery Press, n.d.), 84-86

${ }^{61}$ Spiros Zodhiates, The Complete Word Study New Testament. King James Version. (Chattanooga, Tennessee: AMG Publishers, 1991).

62 The Amplified New Testament. (Grand Rapids, Michigan: Zondervan Publishing House, 1958).
} 
orang. Haruslah ia memberikan Firman yang murni, yaitu ajaran yang

benar, yang tidak dicampur dengan tafsiran-tafsiran yang salah. ${ }^{63}$

Seorang pemimpin tidak boleh berpuas diri karena sudah mendapat ijazah dan gelar. Dalam menangani setiap tugas dan tanggung jawabnya, ia harus mempersiapkannya dengan sebaik dan seteliti mungkin dengan jalan belajar dengan tekun.

\section{Belajar Secara Berkelanjutan}

Ketika Paulus mengatakan, "Usahakanlah supaya engkau layak di hadapan Allah sebagai seorang pekerja yang tidak usah malu, yang berterus terang memberitakan perkataan kebenaran itu" (2 Timotius 2:15), Paulus memaksudkan bahwa hendaknya Timotius belajar dengan tekun bukan saja dalam suatu limit waktu tertentu, melainkan secara terus menerus. Senada dengan ini, A.B. Susanto, mengatakan, "Pemimpin juga dituntut untuk memiliki keluasan wawasan dan pengetahuan yang berarti harus ada kesadaran untuk selalu mau belajar." ${ }^{64}$

Menyinggung tentang pentingnya belajar secara berkelanjutan, Dag Heward-Mills, mengatakan: There are many people who think that they know all there is to know in the word of God. No one knows everything! The unconscious, incompetent person is pitiful because he does not know that he does not know! (Ada banyak orang yang berpikir bahwa mereka sudah mengetahui semua yang perlu untuk mereka ketahui akan firman Tuhan. Tidak seorangpun yang telah mengetahui segala-galanya. Orang yang tidak sadar dan tidak berkompeten adalah orang yang menyedihkan karena ia tidak tahu bahwa ia tidak tahu!). ${ }^{65}$

Pemimpin sejati adalah pemimpin yang senantiasa berkembang dan bertumbuh sesuai dengan tuntutan dan kebutuhan dalam konteks kepemimpinan yang ada. Untuk memiliki berbagai ketrampilan diperlukan suatu usaha dan kerja keras dengan disiplin serta komitmen diri seseorang untuk terus belajar tentang berbagai hal yang membuat kepemimpinannya semakin efektif, produktif dengan fleksibilitas kepemimpinan yang berhasil.

Seorang pemimpin perlu belajar tentang berbagai gagasan, pendapat dan membuat umpan balik untuk mengadakan perubahan bagi organisasi bawahan dan diri sendiri. Seperti yang ditulis oleh Marshall Gold Smith dan kemudian dikutip oleh Frances Hesselbein:

Mintalah masukan dari mereka yang terkait tentang keselarasan perilaku dan kegiatan Anda dan visi Anda, belajarlah dari apa yang dikatakan orang lain tentang diri dan peluang Anda pada masa

\footnotetext{
${ }^{63}$ John Wesley Brill, Tafsiran Surat Timotius dan Titus. (Bandung: Kalam Hidup, 1978), 80

${ }^{64}$ A.B. Susanto, Meneladani Jejak Yesus Sebagai Pemimpin. (Jakarta: PT Grasindo, 1997),

${ }^{65}$ Dag Heward-Mills, "After You Are Saved, Your Mind is Still the Same; It Must be Renewed," Church Growth, Summer 2005, 10
} 
mendatang, buatlah skala prioritas dan fokuslah pada beberapa bidang penting untuk memperoleh perubahan serta lakukan tindakan lanjut untuk memastikan pelaksanaan yang efektif. Dengan menuntaskan langkah-langkah penting ini, Anda akan dapat tumbuh dan menjadi pemimpin masa depan yang Anda inginkan. ${ }^{66}$

Belajar secara berkelanjutan merupakan suatu usaha dalam membangun gaya hidup yang berintegritas dan yang setia pada kebenaran. ${ }^{67}$ Sangat menarik apa yang dikatakan oleh Paulus dalam 2 Timotius 4:13. "Jika engkau ke mari bawa juga jubah yang kutinggalkan di Troas di rumah Karpus dan juga kitab-kitabku, terutama perkamen itu." Sebagaimana penulis telah kemukakan di depan, bahwa surat 2 Timotius ini ditulis oleh Paulus menjelang hari kematiannya di Roma. Namun pun demikian, Paulus masih saja memesan kitab-kitabnya, terutama perkamen itu. Hal ini menunjukkan bahwa Paulus menerapkan pada dirinya apa yang disebut "long life education" (pendidikan sepanjang hidup). Bagi Paulus tidak ada kata "sudah terlalu tua" untuk belajar.

Denis Waitley, cendekiawan, penulis dan penceramah, menasihatkan: "Teruskan pendidikan Anda tidak peduli berapa umur Anda." ${ }^{68}$ Tidak diragukan lagi bahwa kemampuan Paulus dalam menangani berbagai keadaan yang rumit dalam pelayanannya adalah karena kegigihannya belajar secara berkelanjutan. Belajar secara berkelanjutan membuat Paulus menjadi cakap dalam melaksanakan pelayanannya. Hal ini sepatutnya ditiru dan diteladani oleh para pemimpin masa kini yang akan tampil cakap dalam melayani Tuhan. Hal ini pula yang membuat penulis, walaupun sudah menikah, sudah punya anak, dan punya banyak tanggung jawab, memutuskan untuk kembali belajar di STT Jaffray Makassar. Penulis menyadari bahwa untuk bisa melayani dengan baik, dan mendukung suami dalam pelayanannya, mau tidak mau, penulis harus belajar, dan belajar terus.

\section{IMPLIKASI PEMIMPIN YANG MEMILIKI INTEGRITAS}

\section{Penyebab Pemimpin Tidak memiliki Integritas Tidak Memiliki Keyakinan}

Salah satu penyebab seseorang tidak memiliki integritas adalah karena yang bersangkutan tidak memiliki keyakinan, misalnya: ketika ia menghadapi tekanan sosial yang besar. Pemimpin seperti ini, setiap kali menghadapi masalah, akan tampak bengong, tidak tahu mengapa dan

\footnotetext{
${ }^{66}$ Frances Hesselbein, The Leader of The Future. (Jakarta: Gramedia, 2000), 239

67 Watchman Nee, Pekerja Kristus. (Bandung: Kalam Hidup, n.d.), 95-101.

${ }^{68}$ Denis Waitley, Kerajaan Pikiran: Pelajaran Untuk Memimpin dan Berhasil di Dunia Yang Berdasarkan Pengetahuan. (Jakarta: Binarupa Aksara, 1996), 71.
} 
untuk apa ia ada di sana. Apa yang ia dapat lakukan. Ia bingung, sebab ia tidak punya keyakinan, apakah ia benar atau salah. Dan apakah ia perlu mundur atau jalan terus. Frank Damazio mengatakan:

Membangun sebuah keyakinan dimulai dengan Firman Allah, bukan dengan pemikiran-pemikiran manusiawi, budaya atau pengalamanpengalaman. Mempergunakan hermenetika yang tepat dan renungan, kita mempelajari Firman Allah untuk menggali kebenaran yang terletak di situ. Kita membangun prinsip-prinsip yang mencerminkan kebenaran Alkitab. Prinsip-prinsip ini perlu diartikulasikan sebagai keyakinankeyakinan yang manusia dapat terapkan di dalam pelbagai lingkungan kehidupan. Keyakinan-keyakinan yang selaras dengan berita Alkitab biasanya menentang keinginan dasar alamiah lebih rendah kita. ${ }^{69}$

Sebuah keyakinan adalah sebuah prinsip Alkitabiah yang dimaksudkan untuk ditaati apapun harganya. Sebuah keyakinan tidak pernah berubah. Ia secara mutlak tidak mengizinkan berbalik atau berkompromi. Lebih jauh, Frank Damazio, mengatakan:

Para pemimpin perlu mengartikulasi kemutlakan-kemutlakan Alkitab kepada suatu masyarakat yang telah kehilangan jalannya. Masyarakat tidak mempunyai keyakinan-keyakinan bagi keluarga, nilai-nilai, moralitas, kejujuran, atau integritas. Disayangkan banyak pemimpin gereja telah mengkompromikan nilai-nilai dan moralitas mereka tapi tetap tinggal di dalam kepemimpinan. Ini telah mendatangkan celaan besar atas gereja. ${ }^{70}$

Laurie Beth Jones, mengatakan: "Keyakinan pada diri sendiri adalah salah satu kualitas kepemimpinan yang sangat menentukan, sebab 'keluarga yang terpecah belah tidak dapat bertahan.' Pemimpin yang maju mundur menyampaikan pesan yang sangat kabur."

Menurut Titus Tambaru, seorang anggota Majelis Gereja, bahwa "Gereja membutuhkan pemimpin yang akan berdiri dan memegang teguh prinsip-prinsip dan keyakinan-keyakinan yang Allah berikan kepadanya." ${ }^{72}$ Itulah pemimpin yang berintegritas dengan keyakinan-keyakinan yang mengayomi Firman Allah, kekudusan, dan gereja. Seorang pemimpin tidak boleh menyerah kepada filsafat modern atau apa yang disebut filsafat kristen yang baru yang merampas kebenaran Alkitab dari gereja.

\section{Tidak Memberi Penghargaan}

Hal lain yang dapat menyebabkan seorang pemimpin untuk tidak memiliki integritas adalah kebiasaannya untuk tidak memberikan kepada orang lain penghargaan yang merupakan hak mereka. Ia takut ada orang lain yang punya gagasan yang lebih baik atau lebih pintar daripadanya.

69 Frank Damazio, Pemimpin Barisan Depan: Sebuah Angkatan Baru Pemimpin Guna Menghadapi Masa Depan. (Jakarta: Harvest Publication House, 1995), 17

${ }^{70}$ Ibid,

${ }^{71}$ Laurie Beth Jones, Yesus: Chief Executive Officer. (Jakarta: Mitra Utama, 1997), 14

${ }^{72}$ Titus Tambaru, Wawancara oleh penulis, Makassar, 23 Nopember 2007. 
Penghargaan dalam bentuk pujian atau sanjungan memiliki kekuatan, nilai dan pengaruh yang sangat besar. Fred Smith, mengatakan: "Pujian merupakan sesuatu yang berharga sehingga harus digunakan ..."73 Lebih jauh, Smith mengatakan:

Seorang pendeta terkenal langsung mengikuti saya dan menghilangkan sengatan dengan memberikan pujian kepada jemaat. Dia mengatakan bahwa mereka adalah orang-orang yang dunia butuhkan dan jika setiap orang sebaik mereka, maka tidak akan ada masalah. Sesudah dia selesai berbicara tentang orang-orang yang baik dan manis, untuk pertama kali saya menyadari kekuatan dari sanjungan yang cerdik. ${ }^{74}$

David J. Schwartz, mengatakan: "Pujilah bawahan secara pribadi di setiap kesempatan. Puji kerja sama mereka. Puji setiap usaha ekstra mereka. Pujian satu insentif terbesar yang dapat anda berikan kepada orang lain, dan tidak merugikan." 75

Markus Lingga, seorang pendeta dan gembala, mengatakan bahwa "penghargaan yang wajar dalam bentuk pujian, ucapan terima kasih, dan atau hadiah bagi orang yang layak untuk menerimanya memiliki nilai yang sangat penting." ${ }^{76}$ Sebaliknya, Alexander Rammang, juga seorang pendeta dan gembala, mengatakan, bahwa "pemimpin yang kikir atau menganggap haram untuk memberi penghargaan kepada orang lain dapat menjadi tidak populer dan tidak dipercayai." $" 77$

Pemimpin yang tidak suka memberi pujian dan penghargaan kepada orang lain, cepat atau lambat, akan menjadi kurang populer dan kurang diterima. Hal ini akan membuat yang bersangkutan untuk menghalalkan berbagai cara guna mempertahankan popularitasnya, yang tanpa disadarinya merusak integritasnya.

\section{Ketidakterbukaan}

Hal yang ketiga yang dapat menyebabkan seorang pemimpin untuk tidak memiliki integritas adalah ketidakjujuran dan ketidakterbukaan tentang siapa dirinya. Ada orang yang tidak suka menjadi dirinya sendiri dan senang membesar-besarkan keberhasilannya. Orang-orang seperti ini terjebak dalam perbuatan menutup-nutupi kesalahan di masa lalu, bahkan ciri khas pribadi yang tidak memuaskan atau tidak menyenangkan dirinya sendiri.

Sendjaya mengatakan: "Orang yang berintegritas tidak memiliki sesuatu yang ditutup-tutupi atau disembunyikan. Semakin luas pengaruh

\footnotetext{
${ }^{73}$ Fred Smith, Memimpin Dengan Integritas. (Jakarta: Yayasan Pekabaran Injil Immanuel, 2002), 159

${ }^{74}$ Ibid, hal. 76.

${ }^{75}$ David J. Schwartz, Keajaiban Berpikir Besar. (Jakarta: PT. Pustaka Delapratasa, 1997), 300.

${ }^{76}$ Markus Lingga, Wawancara oleh penulis, Makassar, 21 Nopember 2007.

77 Alexander Rammang, Wawancara oleh penulis, Makassar, 25 Nopember 2007.
} 
seseorang, semakin besar transparansi dan akuntabilitas yang ia tunjukkan." 78

Seorang pemimpin sejati akan mengatakan, "Saya adalah pemimpin yang transparan. Saya tahu kekuatan saya ada dalam keterbukaan dan kejujuran saya dengan orang-orang lain." ${ }^{79}$ Selanjutnya, Laurie Beth Jones, mengatakan:

Saya terbuka bagi orang lain dan gagasan-gagasan mereka. Saya tahu bahwa orang-orang lain mungkin memegang bagian dari teka-teki yang saya tidak pegang. Saya mengakui sumbangan-sumbangan mereka secara terbuka dan bebas. Saya memberi mereka penghargaan yang pantas mereka peroleh. ${ }^{80}$

\section{Sikap Egoisme}

Hal lain lagi yang dapat menyebabkan seorang pemimpin tidak memiliki integritas adalah sikap yang dikendalikan ego. Menurut Fred Smith, bahwa: "Orang-orang yang dikendalikan ego akan memuaskan egonya dalam setiap tujuan, sementara orang-orang yang dimotivasi oleh tanggung jawab akan membuat dia mengorbankan egonya bagi suatu tujuan."

Banyak orang percaya bahwa tidak ada korelasi antara integritas dan kinerja. Tetapi mereka ini keliru. John Naisbitt, seorang penceramah dan penulis mengatakan:

Integritas dan kinerja tidak berada pada ujung-ujung yang berlawanan dalam suatu kontinum. Ketika orang bekerja untuk sebuah organisasi yang mereka percaya adil, di mana setiap orang bersedia menyerahkan diri agar pekerjaan selesai, di mana tradisi loyalitas dan perhatian merupakan indikasi mutu, orang bekerja untuk mencapai tingkat yang lebih tinggi. Nilai-nilai di sekeliling mereka menjadi bagian dari mereka, dan mereka berpikir tentang pelanggan sebagai seseorang yang kepadanya mereka berutang produk dan jasa sebaik mungkin. ${ }^{82}$

Alexander Bollo, seorang pendeta dan gembala, mengatakan: "Mestinya dalam diri seorang pemimpin tidak ada tempat bagi sifat egoisme, karena hal itu akan menghambat dia untuk menjadi seorang pemimpin yang berintegritas." 83 Senada dengan itu, Yusuf Tandy, juga seorang pendeta dan gembala, mengatakan, "Egoisme dapat merusak citra diri seorang pemimpin, karena itu seorang pemimpin harus menjaga diri

${ }^{78}$ Sendjaya, "Memimpin Dengan Integritas," lead.sabda.org; diakses tanggal 22

Oktober 2007; tersedia di http://www.lead.sabda.org/_pdf/memimpin_dengan_integritas.pdf

${ }^{79}$ Laurie Beth Jones, Yesus: Chief Executive Officer. (Jakarta: Mitra Utama, 1997), 272.

${ }^{80}$ Laurie Beth Jones, Yesus: Chief Executive Officer. (Jakarta: Mitra Utama, 1997), 272.

${ }^{81}$ Fred Smith, Memimpin Dengan Integritas. (Jakarta: Yayasan Pekabaran Injil Immanuel, 2002), 20

${ }^{82}$ John Naisbitt, Global Paradoks. (Jakarta: Binarupa Aksara, 1994), 176

${ }^{83}$ Alexander Bollo, Wawancara oleh penulis, Makassar, 25 Nopember 2007. 
dari sifat itu." ${ }^{84}$ Seorang pemimpin harus mengembangkan sistim tata nilai yang mencakup integritas, orang lain, dan sinergitas yang akan memungkinkan setiap orang yang dipimpinnya dapat menjalankan fungsi masing-masing bagi tercapainya tujuan yang telah ditetapkan.

\section{Kebutuhan Seorang Pemimpin yang Berintegritas}

Menjadi seorang pemimpin menuntut disiplin diri yang kuat dan disiplin ini hanya bisa ada apabila ada niat yang sama kuat pula. Tidak hanya itu, faktor utama untuk tetap menjaga integritas selama masa kepemimpinan hendaknya didasarkan pada rasa takut akan Allah sebab pada akhirnya kita tetap harus memberi pertanggungjawaban kepada Allah sendiri (bandingkan lTesalonika 5:23). Berikut ini beberapa kebutuhan yang perlu diperhatikan oleh seorang pemimpin.

\section{Mendengar Apa Kata Firman Allah}

Firman Allah akan memberi tuntunan dan sekaligus kekuatan bagi seorang pemimpin untuk menjalankan tugas dan tanggung jawabnya. Firman Allah perlu dibaca dan direnungkan setiap hari. Saat teduh harus dijadikan sebagai aktivitas rohani rutin oleh seorang pemimpin. Seorang pemimpin tidak boleh membiarkan Iblis atau dirinya sendiri menipu dengan mengatakan bahwa pemimpin sudah tidak layak lagi menerima firman Allah. Ketidaklayakan adalah merupakan suatu sikap yang selalu harus ada namun seorang pemimpin membutuhkan firman Tuhan untuk bisa mengetahui dan bertahan dalam kehendak Tuhan. R.C. Sproul, mengatakan: "Cara satu-satunya untuk menghindari legalisme dan antinomianisme adalah belajar Firman Tuhan dengan serius. Hanya baru setelah itu kita akan diberikan petunjuk dengan tepat tentang apa yang berkenan dan apa yang tidak berkenan kepada Allah." ${ }^{\circ 5}$

Kepada Timotius, Rasul Paulus menulis, demikian: "Tetapi hendaklah engkau tetap berpegang pada kebenaran yang telah engkau terima dan engkau yakini ..." (2 Timotius 3:14). Paulus memberi pesan supaya Timotius, pemimpin yang masih muda itu, tetap berpegang pada kebenaran, yaitu Firman Allah. Florence Bulle mengatakan bahwa Paulus "memberi tanggung jawab penuh kepada Timotius untuk memelihara Injil ..." "\$6

Menurut Paulus Pabeno, seorang pendeta dan gembala serta pejabat struktural dalam sebuah organisasi, mengatakan bahwa, "Seorang pemimpin perlu memiliki kehausan/kelaparan akan firman Allah, terhadap ayat-ayat firman Tuhan, ia harus melahap sebisa mungkin. Seorang pemimpin tidak boleh beranggapan bahwa ia sudah tahu semua firman Allah, tetapi dia harus mendengarkan apa yang Allah sampaikan melalui

\footnotetext{
${ }^{84}$ Yusuf Tandy, Wawancara oleh penulis, Makassar, 26 Nopember 2007.

85 R.C. Sproul, Kebenaran-Kebenaran Dasar Iman Kristen. (Malang: Seminari Alkitab Asia Tenggara, 1997), 340.

${ }^{86}$ Florence Bulle, Berbagai Tipuan Dalam Pelayanan. (Malang: Gandum Mas, 1997), 104.
} 
firmanNya." ${ }^{87}$ Seorang pemimpin patut "Berdiam diri untuk mendengarkan masukan atau nasihat dari Firman Tuhan atau suara Roh Kudus." ${ }^{88}$

Pemazmur berkata, "Firman-Mu itu pelita bagi kakiku dan terang bagi jalanku" (Mazmur 119:105). Selanjutnya dikatakan, bahwa: "Segala tulisan yang diilhamkan Allah memang bermanfaat untuk mengajar, untuk menyatakan kesalahan, untuk memperbaiki kelakuan dan untuk mendidik orang dalam kebenaran" (2 Timotius 3:16).

Tidak ada jalan lain yang olehnya seseorang dapat menjadi pemimpin yang berintegritas, kecuali ia rela membuka hidupnya untuk mendengar firman Allah. Dia harus menjadikan firman Allah sebagai pelita pada kakinya dan terang pada jalannya yang akan menuntunnya supaya tidak menyimpang ke kanan atau ke kiri. Seorang pemimpin perlu menjadi seperti anak kecil yang rela diajar oleh firman Allah. ${ }^{89}$ Dalam Mazmur 19:812, Daud mengatakan:

Taurat TUHAN itu sempurna, menyegarkan jiwa; peraturan TUHAN itu teguh, memberikan hikmat kepada orang yang tak berpengalaman. Titah TUHAN itu tepat, menyukakan hati; perintah TUHAN itu murni, membuat mata bercahaya. Takut akan TUHAN itu suci, tetap ada untuk selamanya; hukum-hukum TUHAN itu benar, adil semuanya, lebih indah dari pada emas, bahkan dari pada banyak emas tua; dan lebih manis dari pada madu, bahkan dari pada madu tetesan dari sarang lebah. Lagipula hamba-Mu diperingatkan oleh semuanya itu, dan orang yang berpegang padanya mendapat upah yang besar.

Tidak ada cara lain untuk mengenali kehendak Allah dan pimpinanNya selain daripada memperhatikan apa yang dikatakan oleh FirmanNya. Karena itu seorang pemimpin patut selalu berpedoman pada Firman Allah.

\section{Bergantung Pada Pimpinan Roh Kudus}

Tanpa ragu kepemimpinan Yesus dalam masa hidupNya yang relatif pendek, 33 tahun, telah menembus ruang dan waktu serta memberikan warna yang sangat mendalam bagi dunia. PengikutNya melewati batas negara, bangsa, suku bangsa serta meliputi berbagai latar belakang budaya. Lebih-lebih lagi pola suksesiNya telah berhasil menurunkan pemimpinpemimpin lain yang disegani dan dihormati dalam percaturan dunia Internasional juga, setelah rentang masa 2000 tahun. Hal ini sangat jelas mengalahkan dinasti, kerajaan serta republik yang dipimpin oleh berbagai pemimpin yang sangat hebat dan sangat dicintai pada zamannya sekalipun.

Dalam mengomentari kepemimpinan Yesus yang luar biasa itu, A.B. Susanto, mengatakan:

Roh Kuduslah yang membuat Yesus tampil berkarisma. Dari diriNya terpancar kekuatan pribadi yang membuat banyak orang percaya kepadaNya. Bahkan Ia mampu membuat para pengikutNya

\footnotetext{
${ }^{87}$ Paulus Pabeno, Wawancara oleh penulis, Makassar, 25 Nopember 2007.

${ }^{88}$ Daud Kurniawan, Kerajaan Allah di Antara Kita. (Bandung: Kalam Hidup, 2006), 81.

${ }^{89}$ Bandingkan Lukas 18:17.
} 
meninggalkan segala-galanya guna mengikuti Dia dan berkarya bersama-sama dalam satu tim kerja yang padu dan konsisten... ${ }^{90}$

Alexander Rammang, mengatakan, "Kehadiran, peran, dan pengaruh Roh Kudus sangat penting dan sangat dibutuhkan oleh seorang pemimpin yang baik dan berintegritas." 91 Daud Kurniawan, mengatakan, "Roh Kudus berperan besar dalam perkembangan pola hidup." ${ }^{92}$ Selain daripada itu, seorang pemimpin memerlukan apa yang disebut kedalaman spiritual. Ruang-ruang kosong di dalam jiwa seorang pemimpin haruslah diisi dengan Roh Kudus sehingga dia dapat melayani dengan kedalaman spiritual. ${ }^{93}$

Roh Kudus yang dinamis dan dapat menembus itu akan memandu pelayanan para pemimpin. AnugerahNya memampukan para pemimpin untuk melayani dalam kerendahatian dan kesederhanaan. Para pemimpin harus belajar untuk mendengarkan suara dan bergantung kepada Roh Kudus. Florence Bulle mengatakan, "Kita membutuhkan kearifan rohani yang berasal dari karunia Roh Kudus." 94

Tak ada seorang pemimpin yang mampu melintasi medan kepemimpinannya dengan sukses seorang diri. Ia harus selalu belajar untuk bergantung pada pimpinan Roh Kudus.

\section{Memiliki Karakter yang Baik}

Seorang pemimpin dinilai bukan dari hal "ke mana" ia mengarahkan orang-orang yang mengikutnya, tapi lebih berdasarkan "bagaimana" ia mengarahkan mereka. Mereka akan selalu memperbincangkan karakter pemimpin sebagai manusia, bukan hanya keahlian memimpin yang dimilikinya. Philipus Patana, seorang pendeta dan gembala, mengatakan bahwa, "Mereka yang memutuskan untuk mengikut seorang pemimpin berharap bahwa pemimpin yang mereka ikuti itu memiliki kepribadian yang lebih baik daripada mereka." ${ }^{95}$ Karena alasan inilah, karakter memiliki peran yang sangat signifikan dalam kepemimpinan.

Defenisi sederhana dari karakter adalah "kerelaan melakukan yang benar sekalipun sulit." 96 Berkaitan dengan ini, seorang pemimpin dituntut untuk bisa membuat keputusan yang tepat - keputusan yang kadangkala bertentangan dengan keinginan, emosi, kata hati, kecenderungan umum, dan akal sehat. Karakter pemimpin berkaitan dengan kerelaan untuk membuat keputusan yang benar dan yang harus dilakukan.

${ }^{90}$ A.B. Susanto, Meneladani Jejak Yesus Sebagai Pemimpin. (Jakarta: PT Grasindo, 1997), 5

${ }^{91}$ Alexander Rammang, Wawancara oleh penulis, Makassar, 25 Nopember 2007.

${ }^{92}$ Daud Kurniawan, Kerajaan Allah di Antara Kita. (Bandung: Kalam Hidup, 2006),

93 Frank Damazio, Pemimpin Barisan Depan: Sebuah Angkatan Baru Pemimpin Guna Menghadapi Masa Depan. (Jakarta: Harvest Publication House, 1995), 12.

${ }^{94}$ Florence Bulle, Berbagai Tipuan Dalam Pelayanan. (Malang: Gandum Mas, 1997), 164.

${ }^{95}$ Philipus Patana, Wawancara oleh penulis, Makassar, 25 Nopember 2007.

96 Andy Staenly, "Pemimpin Yang Layak Diikuti," lead.sabda.org; diakses 22 Oktober 2007; tersedia di http://lead.sabda.org/?title=pemimpin_yang layak_diikuti 
Sehubungan dengan pemimpin yang berintegritas, Yusuf Tandy, mengatakan bahwa "ada harga yang harus dibayar ketika seorang pemimpin memutuskan untuk melakukan yang benar. Waktu, uang, kesempatan, reputasi, dan bahkan kemajuan karier terkadang harus dipertaruhkan, meski setidaknya untuk jangka waktu pendek." ${ }^{97}$ Seringkali orang beranggapan bahwa hal-hal dilematis seperti ini akan menghilang begitu kesuksesan sudah ada dalam genggaman. Ini asumsi yang salah karena kesuksesan justru meningkatkan risiko. Mardin Tambe, Ketua Badan Pengurus Majelis Gereja KIBAID Klasis Makassar, mengatakan, "Ketika kesuksesan sudah dicapai, ada satu tantangan yang tak bisa dihindari, yaitu mempertahankan kesuksesan itu. Lebih mudah untuk memenangkan sebuah pertandingan daripada mempertahankan gelar juara." ${ }^{98}$ Seorang pemimpin yang berada di puncak karier mengalami tekanan jauh lebih banyak daripada yang bisa dibayangkan. Pohon yang tumbuh di puncak gunung pasti mengalami terpaan angin yang lebih besar dibandingkan dengan pohon yang tumbuh di lembah.

Melakukan hal yang benar meski harus membayar harga adalah tanda seorang pemimpin yang hebat. Saat seorang pemimpin memutuskan untuk memegang teguh apa yang benar sekalipun keyakinan itu mengorbankan sesuatu yang berharga baginya, maka ia telah menjadi seorang pemimpin yang dapat dipercayai. Fred Smith, mengatakan: "Pemimpin-pemimpin dengan karakter yang kuat memiliki kekuasaan, martabat, dan integritas."

Alkitab memberikan contoh dalam Perjanjian Lama, yaitu kisah Sadrakh, Mesakh, dan Abednego. Mereka bertiga, bersama Daniel, dikirim ke Babilonia sebagai budak. Melalui campur tangan Tuhan, akhirnya mereka memperoleh posisi tinggi dan hidup yang berkelimpahan. ${ }^{100}$ Masalah mulai muncul saat raja Nebukadnezar membangun sebuah patung emas dan memerintahkan setiap orang untuk menyembahnya. Sadrakh, Mesakh, dan Abednego, sebagai orang beriman, tidak mengindahkan perintah raja. Ketika raja mengetahui hal itu, ia memanggil mereka dan memberikan kesempatan kedua kepada mereka untuk menyembah patung itu. Tetapi ketiga pemuda itu tidak membutuhkan kesempatan kedua. Mereka tetap berpegang teguh pada pendiriannya untuk tidak menyembah patung berhala tersebut, meskipun nyawa mereka menjadi taruhannya karena raja memerintahkan mereka untuk dimasukkan ke dalam dapur api yang menyala-nyala. ${ }^{101}$

Ketika ujian terhadap karakter itu datang, sesungguhnya seorang pemimpin diberi sebuah kesempatan untuk menjadi seorang pahlawan.

\footnotetext{
${ }^{97}$ Yusuf Tandy, Wawancara oleh penulis, Makassar, 26 Nopember 2007.

${ }^{98}$ Mardin Tambe, Wawancara oleh penulis, Makassar, 25 Nopember 2007

${ }^{99}$ Fred Smith, Memimpin Dengan Integritas. (Jakarta: Yayasan Pekabaran Injil Immanuel, 2002), 45.

${ }^{100}$ Bandingkan dengan Daniel 1:18-20.

${ }^{101}$ Bandingkan dengan Daniel 3:1-21.
} 
Jika ia berani mengambil resiko untuk melakukan yang benar, saat ia kembali menengok ke belakang, ia akan melihat bahwa pada saat itu ia benar-benar menempatkan diri sebagai seorang pemimpin dan pribadi yang baik dan layak dipercayai.

\section{Memiliki Kerendahan Hati}

A.B. Susanto, mengatakan bahwa "Tidak semua pemimpin memiliki kemampuan untuk berbicara dengan berapi-api. Banyak juga pemimpin yang justru lebih memberikan arti kepemimpinan melalui kesederhanaan dan kerendahan hatinya. Dalam hal ini kekuatan mempengaruhi lahir dari karisma yang disandang." 102

Yesus, pemimpin Yang Mahabesar itu, memberikan konsep kepemimpinan dengan nuansa yang sungguh sangat berbeda dengan konsep kepemimpinan yang pernah ada di dunia ini. Ia dengan gebrakan aktif menggugurkan berbagai konsep yang lebih mengutamakan kekuasaan. Yesus berkata:

Kamu tahu, bahwa pemerintah-pemerintah bangsa-bangsa memerintah rakyatnya dengan tangan besi dan pembesar-pembesar menjalankan kuasanya dengan keras atas mereka. Tidaklah demikian di antara kamu. Barangsiapa ingin menjadi besar di antara kamu, hendaklah ia menjadi pelayanmu (Matius 20:25-26).

Petrus Octavianus, mengatakan:

Oleh karena itu kekuatan rohani dalam kehidupan dan pelayanan seorang pemimpin rohani ialah bilamana ia pada satu kutub berdiri dengan pendirian rohani yang jelas dan pada kutub yang lain ia sungguh seorang yang dapat merendahkan diri untuk menarik hati teman-teman lain. ${ }^{103}$

Daniel Christianus, yang sukses meniti karier sebagai gembala, mengatakan, "Kerendahan hati tidak sama dengan rendah diri."104 Orang yang rendah diri adalah orang yang minder, yang merasa diri tidak mampu, menunjukkan satu sikap kurang mempercayakan diri kepada Tuhan. Rasul Paulus memberikan satu contoh tentang kerendahan hati dengan mengatakan, aku telah menjadi segala-galanya, supaya aku sedapat mungkin memenangkan beberapa orang lain bagi Kristus. Dan segala sesuatu ini kulakukan karena Injil. ${ }^{105}$

Kerendahan hati itu adalah sebuah karya dari Roh Kudus di dalam hidup seorang pemimpin, yang memungkinkan dia untuk dapat berdiri pada pendirian rohani yang jelas dan tegas. Kegagalan seorang pemimpin

${ }^{102}$ A.B. Susanto, Meneladani Jejak Yesus Sebagai Pemimpin. (Jakarta: PT Grasindo, 1997),

${ }^{103}$ Petrus Octavianus, Manajemen dan Kepemimpinan Menurut Wahyu Allah. (Malang: YPPII dan Gandum Mas, 1986), 98. 2007.

${ }^{104}$ Daniel Christianus, Wawancara oleh dengan penulis, Makassar, 25Nopember

${ }^{105}$ Bandingkan dengan 1 Korintus 9:22-23. 
seringkali terjadi oleh karena dia dapat berpendirian rohani yang kuat, tetapi tidak memiliki kerendahan hati. Dengan kata lain, ia hidup dalam kesombongan. Petrus Octavianus mengatakan, bahwa: "Kerendahan hati berjalan bersama-sama dengan keikhlasan, kejujuran dan keterbukaan untuk menerima kekurangan diri sendiri."

\section{PENUTUP}

\section{Kesimpulan}

Setelah pembahasan yang relatif panjang tentang pemimpin yang memiliki integritas, maka dapat disimpulkan bahwa integritas sungguh sangat penting bagi seorang pemimpin. Integritas perlu bagi para pemimpin supaya pilar-pilarnya menjadi superstruktur. Integritas adalah kekuatan konstruksi kepemimpinan. ${ }^{107}$

Bahwa dalam kehidupan seorang pemimpin tidak hanya harus memiliki suatu kehidupan kerohanian yang tinggi tetapi juga harus ditunjang oleh integritas diri dalam kepemimpinannya. Bobot kepemimpinan tidak ditentukan oleh tingginya pendidikan semata atau banyaknya jam terbang dalam pelayanan, melainkan oleh integritas diri.

Pecahnya Kerajaan Israel, hancurnya Kerajaan Yehuda adalah karena rapuhnya integritas para pemimpinnya. Keruntuhan masyarakat juga diawali dengan pemimpin yang kehilangan integritasnya, yang berakibat runtuhnya sendi-sendi norma masyarakat, seperti ayah tidak menjadi teladan, anak-anak mencari figur dari film, televisi dan media lainnya.

Bahwa pemimpin yang berintegritas adalah pemimpin yang selalu mematutkan hidupnya dengan Firman Tuhan, bergantung penuh pada pimpinan Roh Kudus, mengusahakan karakter yang baik, dan selalu menunjukkan sikap kerendahan hati.

\section{Saran-Saran}

Melihat kembali kepada apa yang telah penulis paparkan di atas tentang seorang pemimpin yang memiliki integritas yang merupakan satu bagian kecil dari prinsip untuk menjadi pemimpin yang baik, penulis memberi beberapa saran yang kiranya bermanfaat dalam mengaktualisasikan prinsip dimaksud.

Pertama-tama, para pemimpin hendaknya senantiasa berpedoman pada Firman Allah dan bergantung sepenuhnya pada pimpinan Roh Kudus.

106 Petrus Octavianus, Manajemen dan Kepemimpinan Menurut Wahyu Allah. (Malang: YPPII dan Gandum Mas, 1986), 99.

${ }^{107}$ Saerang, Henoch F., "Integrity", Local Leadership Training Programme, Makassar: 10-13 Oktober 2007, 4 
Kedua, para pemimpin hendaknya senantiasa memelihara sifat kekudusan dan ketulusan di dalam hidup dan kehidupan mereka setiap hari. Ketiga, para pemimpin hendaknya selalu menunjukkan sikap konsisten, keteguhan hati, dan mampu bertahan sampai akhir. Keempat, para pemimpin hendaknya senantiasa belajar dengan tekun dan secara berkelanjutan untuk mendapatkan dan memiliki keluasan wawasan dan pengetahuan yang diperlukan dalam melaksanakan tugas dan tanggung jawabnya. Kelima, para pemimpin hendaknya memelihara apa yang disebut "kolegialitas", yaitu "rasa setia kawan terhadap teman sejawat" dan senantiasa berusaha untuk menjadi teman dan atau mencari teman yang memiliki akuntabilitas. Keenam, para pemimpin hendaknya senantiasa memperhatikan etika pergaulan dan sopan santum, khususnya pada saat membimbing orang yang berlainan jenis kelamin. Dan yang terakhir, para pemimpin hendaknya senantiasa menjadi teladan yang baik dengan selalu menjaga keselarasan dalam perkataan dan perbuatan.

\section{DAFTAR PUSTAKA}

Buku

The Amplified New Testament. (Grand Rapids, Michigan: Zondervan Publishing House, 1958).

A.B. Susanto, Meneladani Jejak Yesus Sebagai Pemimpin. (Jakarta: PT Grasindo, 1997)

Alexander Rammang, Wawancara oleh penulis, (Makassar, 25 Nopember 2007)

Dag Heward-Mills, "After You Are Saved, Your Mind is Still the Same; It Must be Renewed," Church Growth, Summer 2005

Daniel Christianus, Wawancara oleh dengan penulis, Makassar, 25Nopember 2007

Daud Kurniawan, Kerajaan Allah di Antara Kita. (Bandung: Kalam Hidup, 2006)

David Hocking, Rahasia Keberhasilan Seorang Pemimpin. (Yogyakarta: Yayasan Andi, 1994)

David J. Schwartz, Keajaiban Berpikir Besar. (Jakarta: PT. Pustaka Delapratasa, 1997)

Denis Waitley, Kerajaan Pikiran: Pelajaran Untuk Memimpin dan Berhasil di Dunia Yang Berdasarkan Pengetahuan. (Jakarta: Binarupa Aksara, 1996)

Derek J. Tidball, Teologi Penggembalaan. (Malang: Gandum Mas, 1995)

Ensiklopedi Alkitab Masa Kini, Jl. 2. s.v. "Penjara." (Jakarta: Yayasan Komunikasi Bina Kasih/OMF, 1996) 
Florence Bulle, Berbagai Tipuan Dalam Pelayanan. (Malang: Gandum Mas, 1997)

Frances Hesselbein, The Leader of The Future. (Jakarta: Gramedia, 2000)

Frank Damazio, Pemimpin Barisan Depan: Sebuah Angkatan Baru Pemimpin Guna Menghadapi Masa Depan. (Jakarta: Harvest Publication House, 1995)

Fred Smith, Memimpin Dengan Integritas. (Jakarta: Yayasan Pekabaran Injil Immanuel, 2002)

Frederik K.C. Price, Saran-saran Praktis untuk Pelayanan Yang Berhasil. (Jakarta: Yayasan Pekabaran Injil Immanuel, 1993)

Henoch F. Saerang, "Integrity", Local Leadership Training Programme, Makassar: 10-13 Oktober 2007

John Naisbitt, Global Paradoks. (Jakarta: Binarupa Aksara, 1994)

John Wesley Brill, Tafsiran Surat Timotius dan Titus. (Bandung: Kalam Hidup, 1978)

Johny The, Menjadi Pemimpin Unggul Dengan Strategi Marketing Paulus. (Yogyakarta: Yayasan Andi, 2006)

Larry Crabb, Konseling Yang Efektif \& Alkitabiah. (Yogyakarta: Yayasan Andi dan Bandung: Kalam Hidup, 1995)

Laurie Beth Jones, Yesus: Chief Executive Officer. (Jakarta: Mitra Utama, 1997)

Leroy Eims, 12 Ciri Kepemimpinan Yang Efektif. (Bandung: Kalam Hidup, n.d.)

Nehemiah Mimery, Rahasia Tentang Penggembalaan Jemaat. (Mimery Press, n.d.)

Paul R. Van Gorder, "Pendeta Sebagai Seorang Pemimpin” dalam Warren W. Wiersbe, Paul R. Van Gorder, dan Howard F. Sugden, Prioritas Seorang Gembala. (Malang: Gandum Mas, n.d.)

Paulus Pabeno, Wawancara oleh penulis, Makassar, 25 Nopember 2007.

Petrus Octavianus, Manajemen dan Kepemimpinan Menurut Wahyu Allah .(Malang: YPPII dan Gandum Mas, 1986)

Petrus Octavianus, Manajemen dan Kepemimpinan Menurut Wahyu Allah. (Malang: YPPII dan Gandum Mas, 1986)

Philipus Patana, Wawancara oleh penulis, Makassar, 25 Nopember 2007.

R.C. Sproul, Kebenaran-Kebenaran Dasar Iman Kristen. (Malang: Seminari Alkitab Asia Tenggara, 1997)

Ralph Mahoney, Pembentukan Seorang Pemimpin. (Glenoaks, Burbank, USA: World Missionary Assistance Plan, n.d.)

Robert L. Peterson dan Alexander Strauch, Kepemimpinan Agape. (Yogyakarta: Yayasan Andi, 1995)

Saerang, Henoch F., "Integrity", Local Leadership Training Programme, Makassar: 10-13 Oktober 2007

Spiros Zodhiates, The Complete Word Study New Testament. King James Version. (Chattanooga, Tennessee: AMG Publishers, 1991)

Titus Tambaru, Wawancara oleh penulis, Makassar, 23 Nopember 2007. 
Watchman Nee, Pekerja Kristus. (Bandung: Kalam Hidup, n.d.)

William L. Holladay, A Concise Hebrew and Aramaic Lexicon of the Old Testament. s.v. "qadosy" (Grand Rapids, Michigan: Wm. B. Eerdmans, 1971); Joseph Henry Thayer, The New Thayer's Greek - English Lexicon of the New Testament. s.v. "hagios" Peabody, Massachusetts, 1981); Ensiklopedi Alkitab Masa Kini. s.v. "kudus" (Jakarta: Yayasan Komunikasi Bina Kasih/OMF, 1992).

Yakob Tomatala, "Kepemimpinan Kristen dan Pengaruhnya di Abad XXI," Makalah: Reuni STTJ, Makassar, Juli 2001

\section{Internet}

"Integritas, Bukan Karisma," dominggus.com, diakses tanggal 7 Nopember 2007, tersedia di http:/www.dominggus.com/arsip/2005/01/06/ integritas-bukan-karisma

"Kekudusan Yang Kontinyu", pedson.blogspot.com, diakses tanggal 5 Nopember 2007, tersedia di http://www.pedson.blogspot.com/ 2007/06/kekudusan-yang-kontinyu,html

"Pelantikan Anggota KPU Sesuai UU," poskota.co.id, diakses tanggal 9 Nopember 2007, tersedia di http://www.poskota.co.id/news_ baca.asp?id=39992\& $\&$ ik $=6$

"Samsul Bahri Belum Menjadi Anggota KPU," menkokesra.go.id, diakses tanggal 9 Nopember 2007 tersedia di http://www.menkokesra.go.id/ index2.php?option=com_content\&\&do_pdf=1\& $\&$ id $=5942$

"Samsul Bahri Dijenguk Koleganya Dari Unibraw," hariansib.com, diakses tanggal 9 Nopember 2007, tersedia di http://www.hariansib.com/ 2007/11/03/samsul-bahri-dijenguk-koleganya-dari-unibraw/

Andy Staenly, "Pemimpin Yang Layak Diikuti," lead.sabda.org; diakses 22 Oktober 2007; tersedia di http://lead.sabda.org/?title=pemimpin_yang layak_diikuti

Bill Bright, "Konsep Yang Dapat Ditawarkan,” jesuswho.org, diakses tanggal 4 Nopember 2007, tersedia di http://www.jesuswho.org/indonesian/ tc/whatis.htm

Elwin Tobing, "Seputar Kepemimpinan Nasional," theindonesianintitute.org; diakses 22 Oktober 2007; tersedia di http://www.theindonesianinstitute.org/OurViewMarchl.htm

Gen. Ronald R. Fogleman, "Kaitan Integritas dan Kepemiminan," lead.sabda.org; diakses 22 Oktober 2007; tersedia di http:// www.lead.sabda.org/?title=kaitan_dan_kepemimpinan

John C. Maxwell, Mengembangkan Kepemimpinan di Sekeliling Anda. (Jakarta: Professional Books, 1997), 4; Yakob Tomatala, "Kepemimpinan Kristen: Apakah Itu?" lead.sabda.org; diakses tanggal 2 Nopember 
2007; tersedia di http://www.lead.sabda.org/?title=menemukan _pemimpin_kompeten

Joni Liu, "Nilai Sebuah Konsistensi." Pembelajar.com, diakses tanggal 5 Oktober 2007, tersedia di http: //www.pembelajar.com/ wmview.php?ArtID=739\&term=joni+liu

M. Trafikhan Marzuki, "Mencari Figur Gubernur Ideal," suaramerdeka.com, diakses tanggal 9 Nopember 2007, tersedia di http://www.suaramerdeka.com/harian/02/09/24/kha2.htm

Sendjaya, "Memimpin Dengan Integritas," lead.sabda.org; diakses tanggal 22 Oktober 2007; tersedia di http://www.lead.sabda.org/_pdf/ memimpin_dengan_integritas.pdf

Yakob Tomatala, "Kepemimpinan Kristen: Apakah Itu?," lead.sabda.org; diakses tanggal 2 Nopember 2007; tersedia di http://www. lead.sabda.org/ ?title= menemukan_pemimpin_kompeten 